Illinois State University

ISU ReD: Research and eData

Theses and Dissertations

7-13-2021

\title{
But at What Cost? A Rhetorical Analysis of Capitalism, Whiteness, and Their Intersection in Boots Riley's 2018 Sorry to Bother You
}

Kara A. Brummel

Illinois State University, kara.brummel@gmail.com

Follow this and additional works at: https://ir.library.illinoisstate.edu/etd

\section{Recommended Citation}

Brummel, Kara A., "But at What Cost? A Rhetorical Analysis of Capitalism, Whiteness, and Their Intersection in Boots Riley's 2018 Sorry to Bother You" (2021). Theses and Dissertations. 1429.

https://ir.library.illinoisstate.edu/etd/1429

This Thesis is brought to you for free and open access by ISU ReD: Research and eData. It has been accepted for inclusion in Theses and Dissertations by an authorized administrator of ISU ReD: Research and eData. For more information, please contact ISUReD@ilstu.edu. 


\title{
BUT AT WHAT COST? A RHETORICAL ANALYSIS OF CAPITALISM, WHITENESS,
} AND THEIR INTERSECTION IN BOOTS RILEY'S 2018 SORRY TO BOTHER YOU

\author{
KARA A. BRUMMEL
}

76 Pages

This study expands upon previous analyses of Boots Riley's 2018 film satire, Sorry to Bother You. Gramscian concepts are applied as a theoretical framework to analyze the representations of capitalism, Whiteness, and how these systems of power intersect and reinforce one another in modern US culture. The research aims to understand the film's messages about the mutual influence of material and ideological conditions. The film is analyzed for portrayals of capitalism, Whiteness, and Gramscian concepts by evaluating the plot, themes and tones, visual details, character portrayals, and dialogue. Results indicated that critiques of capitalism and Whiteness are present in the film, and the intersection of capitalism and Whiteness allow hegemonic forces to control individuals' ideologies, maintaining social frameworks that oppress groups that are marginalized within our cultural systems of capitalism, Whiteness, and the intersection of both. Implications, limitations, and areas for future research are discussed. KEYWORDS: Gramsci, capitalism, race, Whiteness, ideology, hegemony, oppression, satire 


\title{
BUT AT WHAT COST? A RHETORICAL ANALYSIS OF CAPITALISM, WHITENESS,
} AND THEIR INTERSECTION IN BOOTS RILEY'S 2018 SORRY TO BOTHER YOU

KARA A. BRUMMEL

\author{
A Thesis Submitted in Partial \\ Fulfillment of the Requirements \\ for the Degree of \\ MASTER OF SCIENCE \\ School of Communication \\ ILLINOIS STATE UNIVERISTY
}

2021 
(C) 2021 Kara A. Brummel 


\section{BUT AT WHAT COST? A RHETORICAL ANALYSIS OF CAPITALISM, WHITENESS,}

AND THEIR INTERSECTION IN BOOTS RILEY'S 2018 SORRY TO BOTHER YOU

KARA A. BRUMMEL

COMMITTEE MEMBERS:

Phil Chidester, Chair

Joseph Zompetti

John R. Baldwin 


\section{ACKNOWLEDGMENTS}

First and foremost, I need to thank Dr. Phil Chidester. This would not have been possible without you. I cannot express how grateful I am to have had your guidance and encouragement throughout this whole process. You were always in my corner, and I truly can't thank you enough for your dedication and investment in this thesis. To my committee members, Dr. Zompetti and Dr. Baldwin, your input and help are invaluable. Thank you for sharing this process with me. To my parents, good ol' Dave and Kelley, thank you for your love, support, encouragement, patience, and grace. I know that you didn't understand the process or the stress at times, but you were always there when I needed you. I love you both so much. Kirsten, you get it, bud!! Thank you so much for everything you did to help make this happen. Thank you for sharing the same brain with me so I could bounce ideas off you, thank you for the popcorn reads and formatting assistance, and thank you for being one of the coolest people I'm lucky enough to know. Hannah, thank you for being my kindred spirit. Knowing you is like knowing sunshine. Thank you for being my roommate, line-dancing partner, and puzzle buddy. I've never laughed as much as I did than when we lived together. Sal, thank you for your encouragement and for teaching me to keep my head held high. I miss watching scary movies together to defeat the Sunday scaries. Jason, thank you so much for everything you've done for me. Like, ever. Your support and encouragement through this process helped me more than you know. Thank you for being my biggest hype man, my best friend, my everything. I love you more. Lastly, I want to thank myself. I can't even count many times I wanted to quit. I struggled with poor mental health during this process and having to write was hell. I cried so much. It took me over three years, but I did it.

K. A. B. 


\section{CONTENTS}

Page

ACKNOWLEDGMENTS

CHAPTER I: INTRODUCTION 1

CHAPTER II: REVIEW OF LITERATURE

$\begin{array}{ll}\text { Capitalism } & 4\end{array}$

Main Concepts of Capitalism $\quad 4$

$\begin{array}{ll}\text { Outcomes of Capitalism } & 7\end{array}$

$\begin{array}{ll}\text { Critiques of Capitalism } & 7\end{array}$

Representations and Critiques of Capitalism in Media 11

Capitalism and Race in America $\quad 14$

$\begin{array}{ll}\text { Whiteness in America } & 16\end{array}$

Representations and Critiques of Whiteness in Media 20

CHAPTER III: THEORETICAL DESCRIPTION AND METHODOLOGY 23

CHAPTER IV: ANALYSIS $\quad 29$

Sorry to Bother You Summary 29

Representations and Critiques of Capitalism in Sorry to Bother You 31

Major Representations of Capitalism 32

Supplementary Representations of Capitalism 36

Representations and Critiques of Whiteness in Sorry to Bother You 40

Major Representations of Whiteness 40

Supplementary Representations of Whiteness 43

The Intersection of Capitalism and Whiteness in Sorry to Bother You 45 
Supplementary Representations of Capitalism and Whiteness

Capitalism

Whiteness

Intersection of Capitalism and Whiteness

Theoretical Implications

Practical Implications

Limitations and Future Research

Conclusion 


\section{CHAPTER I: INTRODUCTION}

As a critical scholar, I have always been interested in social equality and power structures. I enjoy analyzing different institutions or frameworks to understand their impact on society and specific groups of people. Two social forces that are commonly examined in society are capitalism and race, more specifically, Whiteness. Capitalism, the economic structure in America, has been under additional scrutiny lately because the ongoing Coronavirus pandemic has greatly impacted the capitalist system, exposing some of the flaws within. For example, the wealth gap between the different social classes has never been greater (McCarthy, 2021). Specifically, the average CEO made 299 times the pay of the median worker compared to the 264-to-1 ratio from 2019. In other words, while thousands of the working-class lost their jobs due to the pandemic, CEOs still saw an increase in their wealth by $\$ 700,000$ last year (McCarthy, 2021). At the same time, Whiteness is a social framework in which White people are perceived as the natural standard for status simply due to their skin color. The 2018 film, Sorry to Bother You, written and directed by Boots Riley, represents a young Black man's journey through the systems of capitalism and Whiteness in America as a way of questioning the systems and how they operate.

It is important to note here that the movie is a satire, and thus operates differently than content with alleged so-called accurate representations (Gring-Pemble \& Watson, 2003). Satirical content exaggerates elements of the story to emphasize different messages, tropes, or morals. It is crucial to be aware that Sorry to Bother You does not intend to project an entirely realistic universe. The film's director, Boots Riley, who is a self-declared communist, asserts that Sorry to Bother You is an obvious critique of capitalism (Wall, 2018). Although the film is 
relatively new, and there is little scholarly research surrounding it, many movie critics support the latter claim from Riley (Lang, 2018; Reklis, 2018; Sculos, 2019; Torchin, 2019; Wall, 2018).

While there is rich literature on capitalism, Whiteness, and Gramsci's concepts, there is little research applying these concepts to Sorry to Bother You. The film has been described in TIME Magazine as "the most politically and culturally relevant movie of the year," thus making it important to analyze (Zacharek, 2018). In chapter two, I describe how capitalism functions both as America's economic system and as an ideology. Capitalism is structured with a freemarket system, where individuals and companies compete with each other to maximize their profits. The competitive market fosters an ideology that working hard will bring financial success to the individual competitors, yet the corporate elite are the ones who benefit from the labor of the working-class. In chapter two, I also explore Whiteness. Because American society was built to benefit White people and Whites have controlled social institutions, White privilege is often invisible. Thus, the ideology of Whiteness posits that White people are the standard against which others are measured. I also provide examples of how capitalism and Whiteness have been portrayed and critiqued in media.

In chapter three, I explore Gramsci's theoretical concepts of hegemony, the subaltern, the gelatinous middle, common sense, good sense, war of position, and war of maneuver. Gramsci (1989) contends that different social frameworks work together to sustain the hegemony, or dominant social system. In chapter four, I describe how specific characters and plot events in Sorry to Bother You exemplify these theoretical constructs. In addition, I analyze the plot, themes and tones, visual details, character portrayals, and dialogue in the film for representations of capitalism and Whiteness. I discover that both social frameworks maintain the hegemony, but these social forces are strongest when they intersect and influence each other. As the film is a 
satirical commentary on actual conditions in America, how these conditions are represented will be carefully analyzed. Through careful examination, I argue that capitalism and Whiteness reinforce one another and influence the relationship between material and ideological conditions. In chapter five, I summarize my findings and the implications they have for scholarship on capitalism, Whiteness, media, and Gramsci. I end this thesis with a discussion of the limitations of this study and suggestions for future research. Because I analyze capitalism, Whiteness, and the influence of their intersection in this thesis, my purpose is to uncover the meaning behind the satirical messages of the mutual influence of material and ideological conditions. 


\section{CHAPTER II: REVIEW OF LITERATURE}

The goal of this research is to explore the themes of capitalism and Whiteness in Sorry to Bother You and how they interact. Through these portrayals in the film, I hope to understand the film's messages about the mutual influence of material and ideological conditions. Capitalism and Whiteness are familiar concepts within the communication field, both with large bodies of scholarship. Understanding the concepts present in Sorry to Bother You is imperative for moving forward with analyzing and discussing the film. As Riley (2018) states that the film is an intentional critique on capitalism, this concept will be explored first in the review of literature. Thereupon, an explanation of capitalism, its critiques, and how it has been observed in media will be reviewed in this chapter. Following, the rich history and influence of race and Whiteness in American culture, as well as Whiteness in media, will be explored. This chapter will conclude with a summary of both concepts, demonstrating how capitalism and Whiteness intertwine.

\section{Capitalism}

\section{Main Concepts of Capitalism}

It is important to mention that while capitalism functions as an economic system, the values associated with capitalism saturate many different aspects of American society, including social, political, and cultural institutions. As a result, capitalism operates as an economic structure and as an ideology, both actively examined and critiqued by scholars and economists. Before understanding how and why capitalism is critiqued, most notably by German philosopher and economist Karl Marx who will be discussed momentarily, it is necessary to understand both the function and values of capitalism, first as an economic structure.

Capitalism is not a recent phenomenon. Prevalent in the West for several hundred years, it has been the ruling economic system in America for centuries. Capitalism is based on the 
private or individual ownership of the means of production (i.e., goods and services) in the pursuit of maximizing profits. It functions through a free-market system, where people or companies make the decisions for their means of production rather than the state or government. The limited government interference allows for these people or companies to compete with one another for profit through supply and demand of products and services (Carlson, 1993; Fishbein, 1988). This spirit of competition within the system feeds into the values associated with capitalism, a core value being the freedom of choice.

Many operating within the capitalist system support it and view themselves as free. McGowan (2013) elaborates on this, saying people see themselves as "free to make money, free to consume what they want, and so on" (p. 4). Individuals have the choice to work or spend money if they want, but the capitalist system is designed to be superficial and money-oriented. To elaborate, the capitalist system urges individuals to strive for "the good life," or a life with "satisfaction of wants as the ultimate goal" (Ott, 2013, p. 737). The pressure to consume and accumulate, there is little to no distinction between legitimate needs and superficial or materialistic wants. This leads the capitalist system to become solely driven by possessions over time, pushing the notion that one can never have enough.

Marx and Engels (1948) believe the need for money in a quantitative sense is what maintains the modern economic system. In a domino effect, greed drives profits, which drives innovation and product development, which means there are more choices available for people who can afford them. Weber (2002) supports this argument, stating that humans are "dominated by the making of money," claiming that a self-interested or greedy mentality helps sustain capitalism (p. 18). With money as motivation, the more one works, the more one can spend. 
Although accumulation of money is the driving force in a capitalist society, business owners and workers also have other motivations between them. Owners aim for large profits for the company, resulting in large profits for themselves. Simultaneously, company owners encourage their employees to work for the good of the company. Workers are encouraged to believe that the more profit a company has, the more the employees' profit will be through the increase of wages and better benefits. Massumi and Aryal (2012) argue that "the capitalist [business owner] identities with the capitalist structure of society, and the worker becomes affectively invested in it" (p. 66). Essentially, the worker embodies the pursuit for capital gain. With business owners and corporations reinforcing the notion that the more labor the workers provide for the business the better the workers' lives will be, capitalism becomes an ideology ingrained into the beliefs and attitudes of the workers. Therefore, the capitalist system tends to favor those with the "pull yourself up by your bootstraps" mentality. Another core value of capitalism is that through diligence, perseverance, and loyalty, one will be rewarded with economic stability, increased wealth, and power (Carlson, 1993; Fishbein, 1988). Supporters of capitalism suggest that rich people are rich because they work for what they earn, while impoverished people are impoverished because they do not work as hard (Siegel, 2002). This belief echoes that of meritocracy, or the belief that the successful deserve their success based on merit and God's favor, compared to the unsuccessful who deserve their failures (Talib \& Fitzgerald, 2015). Ultimately, supporters of modern-day capitalism view the world as economic survival of the fittest (Weber, 2002). However, many take issue with arguments like these, critiquing the capitalist system for the wealth inequality that capitalism breeds. 


\section{Outcomes of Capitalism}

Capitalism has been the economic system in America for more than two centuries. For about three decades between the 1940s and 1970s, all income levels (i.e., working-class, middleclass, upper-class) experienced similar rates of per capita income growth (Price \& Edwards, 2020). In other words, the lower and middle-classes watched their incomes grow at nearly the same rates as those at the top. In the mid 1970s, the middle-class began to dwindle as the wealthiest Americans, specifically the top one percent, gained control of majority of the country's economic growth. As corporations grew, average Americans saw little to no economic growth (Price \& Edwards, 2020). Burton and Weller (2014) claim that:

Corporate CEOs have enjoyed record levels of compensation and corporations have seen record profits, as more and more middle-class Americans are experiencing stagnant wages and vanishing benefits.... In 2004, the average CEO received 240 times more than the compensation earned by the average worker. In 2002, the ration was 145 to 1 . (p. 1)

The authors continue by saying, "CEO compensation packages are often designed with tax avoidance in mind. By being compensated in ways other than direct salary payments, CEOs can take advantage of ever lower taxes on capital income compared to income from work" (Burton \& Weller, 2005, p. 2). More recently, "in 2019, the ratio of CEO-to-typical-worker compensation was 320-to-1" (Mishel \& Kandra, 2020, para. 1). It goes without saying that this extreme wealth inequality begets criticism from scholars and economists.

\section{Critiques of Capitalism}

Those who critique capitalism believe that, while the system allows employees the choice to work and spend, there are significant obstacles to doing so. Karl Marx is one of the most wellknown and influential critics of capitalism, believing that the capitalist system is more oppressive 
than it is liberating (Ackerman, 2014). Marx and Engels (1948) suggest that human labor is the driving force of capitalism. People sell their time and abilities, also known as labor, for the creation of commodities. However, the competition within the capitalist economic system is not limited to just goods and services. The authors argue that "labor produces not only commodities; it produces itself and the worker as a commodity" (p. 71). Marx and Engels believe that workers earn wages through selling their own labor; thus, wages earned equate to the worker themselves. The competition between capitalists, or those who own the means of production (e.g., factories, land, and corporations) influence the supply and demand of commodities, which in turn, determines supply, demand, and wages for workers. Capital, or profit, can only increase through labor, and the more productive capital grows, the more labor and workers are needed to increase demand for profits. When capital grows rapidly, more competition between capitalists and workers arises. While increased profits may seem ideal, in the capitalist system, most of the profits go to the capitalists instead of the workers (Marx \& Engels, 1948). Workers' wages typically remain low, though low wages are no indication of inferior labor (Weber, 2002).

Continuing, Marx and Engels (1948) suggest that capitalism exploits workers rather than corporations, who become enriched at the expense of their workers. This creates a society with a huge wealth gap between social classes, with the bourgeoisie as the elite and powerful, and the proletariat as the poor workers. Thus, capitalism influences the social and economic relationships between people, rather than between people and things (Marx \& Engels, 1948). Similarly, Berger (2005) states that everything is shaped by a society's economic system, which ultimately affects the ideas that people will have, how people interact with one another, the institutions they will establish, and more. Berger contends that "capitalism is not only an economic system but also something that affects attitudes, values, personality types, and culture in general” (p. 47). 
According to Marxist theory, the economic structure is referred to as the base, or the employer and employee relationship. The base influences the superstructure, or the collective culture, political and social institutions, and power structures within society (Marx \& Engels, 1948). Expanding on this, Marx (1964) proclaims:

The production of ideas, of conceptions, of consciousness, is at first directly interwoven with the material activity and the material intercourse of men, the language of real life. Conceiving, thinking, the mental intercourse of men, appear at this stage as the direct efflux from their material behavior. The same applies to mental production as expressed in the language of politics, laws, morality, religion, metaphysics of a people. Men are the producers of their own conceptions, ideas, etc. - real, active men, as they are conditioned by the definite development of their productive forces and of the intercourse corresponding to these, up to its furthest forms. (pp. 74-75)

This quote points to a contradiction and a common critique regarding capitalism. As aforementioned, capitalism provides individuals the choice or freedom to work and "pull themselves up by their bootstraps," or to not work and live in poverty. However, this is an illusion, as this supposed freedom carries a set of ideas that leaves individuals within the system as anything but free. As Marx believes that money is our main motivator, he explains in this quote that capitalism is the starting point for ideas to transfer between humans. He continues to say, "The ideas of the ruling class are, in every age, the ruling ideas: i.e., the class which is dominant material force in society is at the same time the dominant intellectual force" (p. 78). The intellectual force of which Marx speaks is often associated with Gramscian concepts of hegemony, common sense, and ideology. 
Although these Gramscian concepts will be discussed in depth in the third chapter, it is crucial to clarify them and how they operate within capitalism here. First of all, Marx's dominant intellectual force is considered to be those who hold majority of economic, social, and political power. Gramsci (1989) calls this group the core, or hegemon, with hegemony being the control the hegemon has. The hegemon is made up of those who create laws, monitor the economy, and control those living within the civil society. While the hegemon serves as the leadership for the general public, citizens tend to follow these laws and status quo policies without hesitation or second thought, and these universally accepted, and blindly obeyed principles, are what Gramsci calls common sense. Zompetti (2012) states that "common-sensical beliefs largely frame ideological perspectives" (p. 5). In other words, ideology and common sense are synonymous and interchangeable.

Berger (2005) goes on to say that ideology is "any system of logically coherent and widely applicable sociopolitical beliefs. The ruling class, according to this theory, propagates an ideology that justifies its status and makes it difficult for ordinary people to recognize that they are being exploited and victimized" (p. 48). Essentially, Marx is declaring that through establishing and maintaining economic, political, and cultural power, the ruling class, or the bourgeoisie, are the ones who control what and how the general public or civil society thinks. When employers instruct their workers to produce and consume, the base influences a spirit of consumerism throughout society. The superstructure, in turn, adapts the ideology of capitalism to procure more materialistic items. The more individuals acquire, the higher in status they will have within the superstructure (Marx \& Engels, 1948). Essentially, the economic structure impacts social relationships. A small group of elites controlling the beliefs of society creates 
issues for the society, which will be discussed further along with the introduction of Antonio Gramsci within chapter three.

\section{Representations and Critiques of Capitalism in Media}

Because capitalism is such a prevalent force in American society, there are many representations of capitalism that both reify and critique it in the media. As previously established, the economic function and ideology of capitalism go unnoticed to average citizens, meaning that most members of society will not investigate or research capitalism further. Therefore, media can serve as a valuable tool to show the functions and effects of capitalism. Younkins (2014) states that "fiction, including novels, plays, and films, can be a powerful force to educate students and employees in ways that lectures, textbooks, articles, case studies, and other traditional teaching approaches cannot" (p. ix). Essentially, media can become a medium for any message.

Helping promote the capitalist ideology, there have been countless media examples that glorify or celebrate the accumulation of wealth. One example is reality television show Lifestyles

of the Rich and Famous, in which the show's core message needs little explanation given its title. Recent research has linked popular shows like Keeping Up with the Kardashians, My Super Sweet 16, Pimp My Ride, and The Real Housewives series to materialism and consumerism (Chaput, 2011; Lewallen, Miller, \& Behm-Morawitz, 2016). These are only a few examples that project the image that one can never have enough money or enough possessions. However, there are examples that demonstrate critiques of capitalism, as well.

As critiques of capitalism have been present as long as the system itself has been in place, such critiques can be easily found within film and media. Film critic and scholar James Kendrick (1999) states that "the notion that American mass popular art in general and cinema in particular 
work as a means to support the cultural status quo and keep the capitalist economic system in motion has been a basic tenet of Marxist theory" (p. 38). Kendrick mentions that director James Cameron has been known to critique capitalism within his films. Cameron wrote, directed, and co-produced the notable film about class struggles, Titanic, released in 1997. In the star-crossedlovers story following impoverished, proletariat Jack and elitist, bourgeoise Rose, Cameron's capitalist critique becomes evident when Rose decides to leave her wealthy life because she is in love with Jack. With Rose leaving a well-off lifestyle, her actions symbolize that money and power are not things that make someone's life rich, but rather love and happiness. Other instances of capitalist criticism occur when Jack is a likeable character and Rose's alternative romance interest is immediately dislikable, along with Rose's mother and others within their social status. In another instance within Titanic, Rose's alternative love interest attempts to buy her love with a diamond and sapphire necklace, illustrating that the only way he can express desire is through money, gifts, and the exchange of power (Kendrick, 1999). Although Titanic does not inherently deconstruct capitalism, Cameron demonstrates that happiness can be found outside of capitalism through Rose's decision to follow her heart. Cameron's capitalist critiques can be found in other films of his, including Alien (1979), The Abyss (1989), and Avatar (2009) (Kendrick, 1999; Loshitzky, 2012). A notable contradiction is Titanic, though critiquing capitalism, was released inside a capitalist system. Cameron's Titanic was the first film to profit over a billion dollars and was the highest grossing film of all time, until Cameron's Avatar replaced it in 2010 (Hammond, 2013). This paradox exemplifies how complicated, powerful, and all-encompassing the capitalist system is.

There are many other examples in film that suggest happiness can be found outside of the capitalist system. Filmmaker David Lynch has been called "one of the great anti-capitalist 
filmmakers," as his films "show that capitalism is based on flawed premises about the nature of enjoyment, and if we continue to adhere to the capitalist system, we do so at the cost of this enjoyment" (McGowan, 2015, p. 103). McGowan continues to say that most characters in Lynch's films seek happiness or enjoyment rather than the accumulation of money. One example of this is Lynch's 1986 Blue Velvet, in which the protagonist imagines access to the underworld and a different way of life as the key to enjoyment and happiness (McGowan, 2015). Parasite, directed by Bong Joon-ho (2019), is another anti-capitalist film in which "capitalism figures itself as a dominant force that guides the story's destructive momentum" (Annis, 2019, p. 3). British director Duncan Jones has two films, Moon (2009) and Source Code (2011), both sharing anti-capitalist themes of exploitation, suffering, and resistance (Constable, 2018). For example, in Moon, clones become incinerated as blood sacrifices to sustain the capitalist industry. Constable remarks that "the visual metaphor forcefully conveys their complete entrapment within a system that exploits them as labour while creating and disposing of them as a product" (p. 427-428). The exploitation of the clones replicates the critique of capitalism that human bodies become the labor they produce.

One final example of a film containing a capitalist critique is David Fincher's (1999) Fight Club, based on the 1996 novel by Chuck Palahniuk. Jordan (2002) states:

Palahniuk dramatizes a situation in which contemporary culture is made responsible for a crisis in masculinity. However, although Fight Club's take on its protagonist's attempt to resolve this crisis is surely ironic, its logic implies that action is required against the effects of global capitalism, which should be understood not as emasculating but as dehumanizing. (p. 368) 
Fight Club utilizes the literary device of irony to critique capitalism. Mentioning this is vital because Sorry to Bother You is a satirical movie, and satire rests within irony. Irony is when something happens in the opposite manner of what is expected (Johnson et al., 2010). In the traditional sense, satire is an ironic and comedic literary form that points fingers at those in power through actions such as ridicule. It is meant to mock human mistakes or vices, sometimes with the goal of inspiring or creating change (Condren, 2012; Gring-Pemble \& Watson, 2003).

For example, a court jester was the only one who could get away with mocking or teasing a king because it was all in good fun (Condren, 2012). Satire operates differently than content with alleged accurate representations because it exaggerates elements of the story to emphasize different messages, tropes, or morals (Gring-Pemble \& Watson, 2003). Satire is widely used in modern American society and can be a valuable tool to raise important questions about mainstream frames, narratives, and ideology (Anderson \& Kincaid, 2015). When content creators use satire, there is always the risk that the audience might not be sophisticated or educated enough to understand the joke or irony, thus leading to potential misinterpretation of the overall message (Johnson et al., 2015). As will be discussed in chapter four, Sorry to Bother You exaggerates many details about both capitalism and Whiteness to ensure the audience understands the film.

\section{Capitalism and Race in America}

Another element of capitalism is racial differences, specifically between White and Black citizens. As I aim to uncover to themes of how capitalism and Whiteness intertwine in this thesis, it is important to understand how capitalism and race relate to each other in America. As aforementioned, a capitalist system creates different economic or social classes (i.e., lower-class, middle-class, upper-class). These classes are typically seen as a hierarchy of status. Brabec 
(2019) echoes this statement, arguing that "capitalism is not just a system of capital accumulation; it is also a class system in which workers struggle against capitalists, both over their condition as sellers of labor power and potentially over the existence of the capitalist system itself" (p. 41). As capitalism exploits the workers, the intersection of capitalism and race in the United States dates back to slavery. Wood (2015) explains that during slavery, the master and slave relation was legally recognized as property owner and property, respectively - a relationship based on force and dependence through the master's coercion and the slave's subjection to that superior force. Essentially, the master is a free person who exploits the slave because the master believes the slave is naturally inferior. Additionally, Wood claims that "the relationship between capital and labour is, juridically, a relation between free and equal individuals, who... share every legal and political right, up to and including full citizenship" (p. 278). If slaves are not free or equal individuals, they are exploited for their labor and excluded from the capitalist system. Essentially, racial oppression was used as a strategy for capitalists to control the labor force.

Beyond slavery, racial oppression and racism have impacted Black people within capitalism. During the Nixon era and his "Southern Strategy," racial fears of the White workingclass were intentionally used to persuade these citizens to switch their political platforms, bolstering conservative politics, yet hurting the entire working-class, a large percentage of which are White (Brabec, 2019). Today, there are still vast discrepancies among Black and White individuals within the different classes of the capitalist system. To put it simply, race and class are almost undeniably intertwined, and it is difficult to think of one without the other. People use class to assume race, and vice versa (Wolpe, 1986). Wolpe argues that the conditions of the economy are outcomes of the relations and process of the economic system. Because capitalism 
prospers off the exploitation of the working-class, the rate of profit depends on the rate of this exploitation. Continuing, they suggest that the rate of profit "will be the outcome of political, economic, and ideological determinants to the extent that, in the struggle for wages, economic calculation will incorporate considerations of status, gender and race" (Wolpe, 1986, p. 123). In other words, the process of accumulating capital or wealth is a social process contingent upon these determinants of power.

Therefore, the capitalist system exploits racial differences to maintain itself. The persistent argument over race distracts citizens so they do not pay attention to how class differences are what actual divide the general public. For example, there is significant media coverage over how the ongoing coronavirus pandemic is impacting marginalized communities. The news media suggested that Black and marginalized communities were heavily affected by the coronavirus because of underlying health conditions (Morgan, 2021, para. 12). However, Wilson (2020) argues that Black communities are more vulnerable to the harmful effects of the pandemic than White communities due to the deeply rooted economic and social injustices. Furthermore, they claim that "persistent racial disparities in health status, access to health care, wealth, employment, wages, housing, income, and poverty all contribute to greater susceptibility to the virus—-both economically and physically" (para. 4). Supporting Wilson's position, Morgan (2021) argues that the gap in coronavirus outcomes has been portrayed as racial, when in reality, it is economic.

\section{Whiteness in America}

Racial disparities abound in America. These differences have impacted current cultural, social, economic, and political institutions since the beginning of the nation. As Olson (2004) mentions, European ancestors who believe they "settled" the land that is now America 
accomplished this settlement at the expense of people of color. Claiming that White people settled the country and established American society "implies the denial that a society already existed; the creation of society requires the intervention of White men, who are thereby positioned as already sociopolitical beings" (Mills, 1997, p. 13). White men inserted themselves into a position of control and currently remain in control. Essentially, White people, when they sought to establish their civilization in America, made the decision that the people who already resided on the land (largely people of color) were subordinate citizens, characterized as savages and barbarians. The distinction between the civilized and the savage evolved into a WhiteNonwhite dichotomy, with Whites primarily benefitting from society (Mills, 1997). America's origin was created by White people, who developed and established social and political structures to benefit themselves, ultimately advancing a concept referred to as Whiteness.

An important distinction to make is that Whiteness and being White are not equivalent. White is a skin color or a socially constructed racial category, while Whiteness functions as an ideology (Nakayama \& Krizek, 1995). As a result of White people establishing American society and controlling institutions, Whiteness is largely the belief that being White is the natural, universal, normal, and unquestioned standard for citizenship and personhood. Banjo and Jennings (2017) suggest that "because representations of dominant groups are generally ignored... the invisibility of privilege perpetuates the problem of racial construction and racial injustice" (p. 282). Nakayama and Krizek (1995) echo the idea that Whiteness is invisible to society, and as a result, dangerous. Like the ideology of capitalism, Whiteness as an ideology convinces the general public to endorse the idea that White is the normal or natural state of being. This accepted but fabricated idea that White people are the standard allows Whiteness to greatly impact American society. 
Whiteness, as Olson (2004) states, is more of a social relation than a genetic inheritance; namely, it is what a person does and not what a person is. Allen (1994) writes, "When an emigrant population from 'multiracial' Europe goes to North America... and... by constitutional fiat, incorporates itself as the 'white race,' that is no part of genetic evolution. It is rather a political act: the invention of the "white race"' (p. 22). Most scholars agree that there are no meaningful biological differences between races, thereby indicating that race is a social construction (Banjo \& Jennings, 2017; Chidester, 2008; Mills, 1997; Olson, 2004; “Oppressed White,"2019). Although a social construction, race mainly functions as a way to organize people into separate groups, creating a social order and leading to preferential treatment of one race over another. Consequently, race cultivates and supports "a system of discrimination, hierarchy, and power" (Olson, 2004, p. xvii). Considering that White people established institutions in current American society to benefit themselves, White people remain at the top of racial order and employ their power to remain on top. Nakayama and Krizek (1995) elaborate on this notion, arguing that White people negotiate and maintain their White privilege through speech and images. They state, "White is seen as a non-color... is unmarked... white people only appear after subtraction... Whiteness is only marked in reverse" (p. 299). The authors clarify by explaining that:

Within a discursive system of naming oppression, but never the oppressive class, white can only be a negative, an invisible entity. This characteristic of whiteness is unique to its discursive construction and must be understood as a part of its power and force. Its invisibility guarantees its unstratified nature. (p. 299) 
Through exclusionary tactics, such as othering based on skin color and debates over citizenship rights that disadvantage people of color, race has essentially been used as a form of political power and domination.

Whiteness in America has allowed for White people to secure and protect privileges in society (Olson, 2004). These privileges commonly manifest in public, psychological, and material advantages or benefits. Olson (2004) provides examples such as "the right to join political parties, access to desired jobs, the ability to compete in an unrestricted market, the capacity to sit on juries, the right to enjoy public accommodations, and the right to consider oneself the equal of another" (p. xx). In addition to these privileges, Olson (2004) suggests that White people are also promised access to land, capital, and markets, granting them a superior social status compared to people of color. Owning these in a capitalist system secures the ability for more profit and power. In the context of slavery, many White people have over a 400-year advantage to owning land, capital, and markets. American society tends to overlook this, which Mills (1997) argues has created a "baseline [for] the existing color-coding configurations of wealth, poverty, property, and opportunities" (p. 73). Economically speaking, Whites dominate most of the world's capital. Specifically, Mills contends that Whites in the United States have substantially twelve times as much median net worth as Black people. Elaborating on this, he states that this "huge disparity in white and black wealth is not remotely contingent, accidental, fortuitous; it is the direct outcome of American state policy and the collusion with it of the white citizenry" (p. 38). Overall, the idea that White people benefit from privilege is an American historical fact. 


\section{Representations and Critiques of Whiteness in Media}

Following the supposition that Whiteness is a dominating force throughout American cultural, social, economic, and political institutions, it is not difficult to imagine the impact it has on film and other media. Beaudoin (2008) endorses this idea, stating that "the media have become such an integral part of a nation that the media system reflects the political, historical, cultural, and economic orientations of that country" (p. 146). For many years, Whiteness has had immense control over the media, so much so that mainstream media cater almost exclusively to White audiences (Tukachinsky, 2015). One instance in which Whiteness is infused in film is through the representations of White people compared to people of color. Critical scholars have been conducting work that reflects this for many years. The U.S. census reveals that Nonwhite people construct over half of the births in the country, proper representation of these people is necessary (Mastro, 2015). However, Erigha (2015) argues that the Hollywood industry has greatly impacted popular culture, but that racial minority characters are often underrepresented and based on stereotypical or damaging assumptions of people in these communities. These negative projections of minorities ultimately perpetuate the dominance of Whiteness in America. Similarly, Gabriel (1996) suggests that Whiteness promotes this negative presentation of the marginalized, but Whiteness can also be disassembled through film studies and critiques.

One form of critique occurring in the film industry is the acknowledgement and the shedding of light on the use of tokenism and token characters. Erigha (2015) claims that it is common for the film industry to cast minorities as token characters, or characters cast to add to the pretense of diversity within the medium. Recognizing tokenism and token characters in media helps uncover the issue of why there is a lack of healthy representation within television and film. Bozarth (2019) mentions tokenism in their thesis involving Sorry to Bother You, which 
will be discussed in chapter four. Bozarth suggests that Cash is used as a symbol for supposed social progress in the film's alternative universe, but this progress is self-serving to the White elite because it supports integrationist rhetoric (Bozarth, 2019). While Bozarth's contribution adds important context to this project and the overall discussion of Whiteness and the film, the current research aims to explore different terrain on the intersection of class and race.

Another way in which Whiteness can be combatted and disassembled in the film industry is through pushing for more representation within films and other media. This is based on the fact that the lack of accurate and substantial representation on and off screen does not reflect the increasing diversity within American culture. In addition to the actors the audience sees on the silver screen, Hollywood has been under pressure to include more writers, directors, creators, and other executives of color (Molina-Guzmán, 2016). In recent years, for example, there has been discussion about viewers boycotting the Oscars due to a lack of nominated people of color (Feeney, 2016). Sorry to Bother You addresses this need for greater representation both in front of and behind the screen by having a predominantly Black cast as well as a Black writer/director, promising to offer a more honest and sincere representation of Black people. Although Riley's (2018) film is satirical, the comedy does not rely on Black stereotypes. The satirical exaggerations lend themselves toward a critique of capitalism and Whiteness, a refreshing take beyond the destructive and negative depictions of people of color seen in satirical films before (Banjo \& Jennings, 2017). Considering this, it is imperative to examine Sorry to Bother You.

To summarize, capitalism is an economic system driven by the acquisition of wealth. Conversely, capitalist values manifest in a powerful ideology that mythically espouses how the more one works, the more money they will have and the better their life will be. In practice, this ideology leads to the (perhaps subconscious and intentional) exploitation of the working-class 
and the substantial wealth gap between the social classes, a common focus of critique among economists and scholars. There are many examples in media that either glorify or critique capitalism, which are important to mention as Sorry to Bother You is an intentional capitalist critique. Moreover, Whiteness in America is an invisible ideology that reinforces how being White is natural, normal, and preferred. This ideology contributes to the deliberate exclusion of people of color and marginalized communities from social and political institutions, and as a result, societal power. Additionally, Whiteness is imbued in the media, resulting in the underrepresentation and lack of accurate portrayals for Black people and people of color. Sorry to Bother You is predominantly Black, on and off screen, thus combatting Whiteness in the media by providing a more genuine depiction of Black people.

In modern society, capitalism and Whiteness are intimately related such that it is almost impossible to separate the two. People can use class status to assume race, and race to assume class status. While the two concepts are deeply interwoven, it is important to note that capitalism exploits race to maintain the system and sustain the class divide. In chapter three, I will investigate the close relationship between capitalism and Whiteness through a deep understanding of Antonio Gramsci's concepts. As there is substantial evidence showing how capitalism and Whiteness intertwine in Sorry to Bother You, using Gramsci as the theoretical framework will assist me in exploring the portrayals of capitalism, Whiteness, and how they interact. Gramsci's concepts will provide a deeper understanding of the film's messages about the mutual influence of material and ideological conditions. 


\section{CHAPTER III: THEORETICAL DESCRIPTION AND METHODOLOGY}

To reiterate, the focus of this project is to explore the intersection between capitalism and Whiteness within Riley's (2018) Sorry to Bother You. Because the film is a satirical commentary on actual conditions in America, I will explore the exaggerated portrayals of capitalism, Whiteness, and how they intersect with the goal to understand the film's messages about the mutual influence of material and ideological conditions. As stated in chapter two, capitalism and Whiteness have impacted American society for centuries. White people have established themselves in dominant positions of economic, social, and political power, leaving Black people and other marginalized communities at a disadvantage. The damaging ideologies that capitalism and Whiteness perpetuate impact the representations of Black citizens within society and the film industry. It is my contention that these types of depictions sustain power imbalances and the domination of Whiteness in our society; thus, it is important to critique and analyze these kinds of media texts to understand how they fill this function of domination and oppression. Sorry to Bother You is unique in that it is a critique of these power imbalances.

Because Sorry to Bother You is a capitalist critique, applying Marxism to elements of the film may seem like the preferred theoretical framework to use. However, one of the downfalls of Marxist theory is the assumption that a society's economic system is the only driving force between the bourgeoisie and the proletariat. Italian philosopher Antonio Gramsci uses similar concepts as Marx, including the idea that the ruling class projects an ideology to exploit workers to keep them from revolting or starting a revolution. Landy (1994) explains that "Gramsci offers more flexible, less monolithic, and less stratified insights into how the relation of state and civil society produces forms of consensus and coercion" (p. 2). Because Gramsci builds his arguments upon the foundations of Marxism to include an economic system as well as other cultural 
identifiers, such as race and Whiteness, Gramsci's theoretical concepts will be utilized for the analysis of this thesis.

It should be noted that Gramsci did not specifically discuss racial issues or race in his writings, though he did examine how different ethnic groups are treated through the discrimination and poor treatment of Southern Italians (Gramsci, 1989). His work instead provides concepts that can be applied to analyzing race in power structures (Hall, 1986). Extending Marxist theory, which postulates that economic class is the single determinant for social status and power, Gramsci argues that there are layers, levels, or intersections of social forces that contribute to social frameworks (Hall, 1986, p. 11). As discussed in chapter two, capitalism, and by extension, race and Whiteness, are common social forces that impact and perpetuate class divisions.

Gramsci contends that civil societies contain a system of domination and marginalization. This system is known as hegemony (Gramsci, 1989). The groups or individuals within the hegemony serving as the agency or figureheads are called the core or hegemon. They wield a majority of power in the society and typically create laws and monitor the economy for the people. As the core is the main power source and leadership for the society it governs, the laws it establishes often go unchallenged, and citizens blindly follow these status quo policies. This widely accepted, unquestioned, and blindly followed ideology is what Gramsci calls common sense. It is important to mention that "common-sensical beliefs largely frame ideological perspectives" (Zompetti, 2012, p. 5). Thus, ideology can be conceptualized as synonymous to common sense, which is how I will advance its explanation and description.

When the civil society obeys the core's established common sense, the core's dominance in society is sustained and strengthened. Members of the civil society who abide by and entrust 
in the core's common sense live within the conjectured periphery of the powerful core. An example of a current American ideology or common sense idea is that hard work will allow one to have a successful career and financial prosperity. This references the "American Dream" narrative that capitalism promotes and Whiteness dominates (Carlson, 1993). Additionally, those with less power who remain on the core's periphery are referred to as "subaltern" groups (Gramsci, 1989, p. 53). The subaltern are fed the core's ideology or common sense, primed to believe that the core will help them, though it conclusively restricts the subaltern from obtaining any power for themselves (Gramsci, 1989). Zompetti (2012) suggests that common sense is meant to entice and coerce the subaltern with the feeling of participation and choice, leading them ultimately to consent to the hegemony's continued dominance. Consenting to be governed by the core, the subaltern repeatedly endorse the hegemony's common sense.

Similarly, Gramsci (1976) acknowledges an imagined middle-class between the subaltern and the hegemon called the "gelatinous" middle (p. 238). This group does not share the same amount of power as the core but is not as marginalized along the peripheral terrain, historically ebbing and flowing between the two. While Gramsci does not advance this specific definition, it is important to mention that there are communities between the proletariat and the bourgeoisie. The gelatinous middle in current American society is often conceptualized as the middle-class, or people who do not live in poverty but are in no means powerful elites.

Another concept of Gramsci's is that of good sense. Good sense is the reimagined and new common sense the subaltern establishes after a revolution against the hegemony (Carroll, 2010; Gramsci, 1989; Green, 2015). Because common sense is the standard or status quo ideology set and reinforced by the hegemon, good sense is the ideology that subaltern groups create with the intention to develop a fairer and more equitable society (Gramsci, 1989). The 
subaltern groups and gelatinous middle can foster good sense through education and group alliance (Gramsci, 1989). Essentially, subaltern groups and the gelatinous middle are capable of becoming critically self-aware of the injustices imposed upon them from the hegemon's common sense, motivating them to transform their conditions in society.

When the subaltern and gelatinous middle become aware of the hegemon's common sense and plan to initiate a counter-hegemonic movement to initiate good sense into society, a war of position takes place. It is here that the movement should plan, organize, and gain strength as they wait for the opportune moment to attack the hegemony (Gramsci, 1989; Zompetti, 2012). The actual attack on the hegemon and its common sense is a war of maneuver. A war of maneuver is most effective when the hegemony's common sense is fragmented or weakened, allowing for good sense to infiltrate and take over (Gramsci, 1989; Zompetti, 2012).

Understanding and connecting Gramsci's theoretical concepts to Sorry to Bother You is crucial to analyzing the film. As I will explore the intersections of capitalism and Whiteness in the film through the Gramscian lens in this thesis, having a rich understanding of Gramsci's concepts is necessary. In chapter four, how capitalism and Whiteness intertwine will be made apparent through evaluating the plot, themes and tones, visual details, character portrayals, and dialogue in Sorry to Bother You.

To begin the analysis process, I will comprehensively watch Sorry to Bother You several times to look for cues representing capitalism, Whiteness, and Gramscian concepts. For the central characters, I will focus on how they dress, their living conditions, the way they talk (e.g., language patterns, code switching), and the ideas they have and share through conversation. The verbal and nonverbal cues of each character provide understanding of their intentions, motivations, and how they fit into the storyline. 
As the film intentionally critiques capitalism, this will be the first theme I examine. Considering the cues above, I will watch for how the characters are represented and used as examples of the proletariat and the bourgeoisie. For example, characters who are in an elite social class may be White, dress fancier, and to have better living conditions. On the other hand, characters in a lower social class will likely be people of color, dress in more casual and affordable clothing, and have mediocre living conditions. Although acquisition of money is capitalism's primary motivation for all classes, there is potential for alternative attitudes about money between the characters and economic classes.

Using the same cues above, I will also analyze Sorry to Bother You for representations of Whiteness. Understanding that code-switching is a common behavior for Black people to deploy, characters who are people of color will likely adjust their language patterns, especially when interacting with the elite (Bozarth, 2019). Because Whiteness is a regime of power, it expects others to adjust to it rather than the other way around. Seeing if the characters of color are adjusting themselves and their manner of presentation to the White elite will be a way of determining the messages about Whiteness that are present in the film. As established in chapter two, Whiteness is also an invisible or unnoticed subject position. Therefore, it is not likely that White characters will discuss their race because it is unnoticed. On the contrary, Black characters and other characters of color are more likely to discuss different struggles associated with their race. Additionally, White characters will likely hold positions of power and fit within the bourgeois class. White characters may also hold different ideas or attitudes about the capitalist system than Black characters and other marginalized groups. This will also provide representations of how capitalism and Whiteness intersect within the film. 
Because capitalism and Whiteness influence each other to determine social groups, I will use the aforementioned cues to search for representations of Gramsci's concepts. The hegemony, or dominant social force will likely manifest as the capitalist structure and Whiteness. The hegemon, then, will appear as the White character(s) in positions of power who promote and advocate for the common sense. This will likely be a message promoting capitalist and Whiteness ideals to the subaltern class. Because of the interconnectedness of capitalism and race, I anticipate that Black characters and other characters of color will comprise the subaltern groups. Characters who will represent the gelatinous middle will likely be White, though it is possible to see a few token characters within this social class. Additionally, one or more members of the subaltern will hold and foster the good sense, an ideology that combats capitalism and Whiteness. If the plot of Sorry to Bother You contains any form of resistance or revolution to represent a war of position and/or war of maneuver, subaltern group members are the ones who will be conducting the actions to revolt against the hegemony in such a manner.

As the film is satirical, character names may also symbolize hidden meanings or messages. Furthermore, any exaggerations within any aspect of the film will be considered and analyzed mentioned for clarity of the satirical content. I will know that content is satirical when it points to human vices and mistakes, or places blame on those in power through hyperbole or understatement. Using a Gramscian lens to analyze Sorry to Bother You's capitalist and Whiteness representations through the plot, themes and tones, visual details, character portrayals, and dialogue will reveal the relationship between material conditions and ideological conditions, aiding in bodies of literature for capitalism, Whiteness, and Gramsci. Taking these elements of the film together, I will be able to assess their collective meanings conveyed by the film and its overall message about the relationship between capitalism and Whiteness in our modern society. 


\section{CHAPTER IV: ANALYSIS}

Within the film, Sorry to Bother You, there are many instances when capitalism and Whiteness are represented through the plot, themes and tones, visual details, character portrayals, and dialogue. To wholly demonstrate how capitalist and Whiteness representations align with Gramsci's theoretical framework and concepts, I will analyze the film in the pages below. I will start with a detailed summary of the main events in the film. There are different cues gathered from numerous comprehensive viewings of the film denoting capitalism, Whiteness, and Gramscian concepts. Providing specific examples, I will subsequently explore the representations and critiques of capitalism and Whiteness within Sorry to Bother You, aligning Gramscian concepts with different characters or events that take place. Keeping in mind that the film is a satire, I will explore the exaggerated portrayals of capitalism, Whiteness, and how they interact. By completing this analysis, I hope to understand Sorry to Bother You's messages about the mutual influence of material and ideological conditions, adding to the bodies of scholarship surrounding film, capitalism, Whiteness, and Gramsci.

\section{Sorry to Bother You Summary}

The plot of the film focuses on Cassius "Cash" Green (played by Lakeith Stanfield), a financially struggling, young, Black man who lives in his uncle's (played by Terry Cruz) garage. Needing money to pay for rent, Cash acquires a telemarketing job selling encyclopedias at a company called Regal View. Meanwhile, another coworker of Cash's, Squeeze (played by Steven Yeun), is organizing a union. Cash initially participates in the strike through a short work stoppage, the purpose of which is to bring employee demands for higher pay and benefits to management. His activist and artist girlfriend Detroit (played by Tessa Thompson) and best friend Salvador (played by Jermaine Fowler) join in this union demonstration, as they are also 
telemarketers for Regal View. However, through using what he calls his "White voice," Cash rapidly increases his sales, and he advances through promotion to a coveted "Power Caller" position. From here, he moves up the corporate ladder and ends his participation in his old coworkers and friends' evolving strike. Accepting the Power Caller position, he physically and symbolically moves away from his friends, all who are uncomfortable with Cash's "White voice" and his new emergence as a Black man in White-dominated spaces.

As a Power Caller, instead of selling encyclopedias, he is now making million-dollar sales of military hardware and contracting slave labor to Regal View's biggest client, Worry Free. Worry Free is "a company that signs people to lifetime work contracts in exchange for free room and board" (Collum, 2018, p. 39). Worry Free, whose marketing is seen everywhere in the background of the film, represents how in this alternative movie universe Americans are desperate enough to volunteer for slave labor because of the lowered wages and poor economy. The CEO of Worry Free, Steve Lift (played by Armie Hammer), takes notice of Cash's ability to successfully make these significant sales and invites Cash to a party at his house. At this party, Cash and the only other Black Power Caller, Mr. ___ (played by Omari Hardwick), are the only two people of color. Throughout the film, Mr. ___'s name is bleeped over, hence the blank space to indicate that his identity is unknown to the audience. Several times during the party, Lift puts Cash on the spot to discuss his life and hobbies, expecting Cash to participate and brag about stereotypical elements of Black culture. Cash awkwardly succumbs to Lift's peer pressure, gaining his approval.

As the party slows down, Lift invites Cash to his office and the two sniff a drug-like white powder. Lift attempts to recruit Cash for a classified project involving genetic manipulation to create human-horse hybrids to maximize labor output and create employees who 
will "hopefully complain less" (Riley, 2018). Most importantly, Lift attempts to persuade Cash to become one of these "Equisapiens," specifically the leader of them. Impressed with Cash's sales abilities, Lift urges Cash to become the "Equisapien Martin Luther King Jr." for the "horse people," offering him $\$ 100,000,000$ and the formula to change him back for a five-year contract (Riley, 2018). Cash would present as the figurehead for the Equisapiens while secretly working for Lift and Worry Free, ultimately preventing them from overtaking the company.

Cash is repulsed by this violation of human rights and publicly shares a video of these Equisapiens, only to find that politicians and representatives are overjoyed that Worry Free has created a way for cheaper and faster labor. An undetermined amount of time passes as Cash quits Worry Free and Regal View, seemingly returning to the life he had at the beginning of the film. The screen cuts to black, and then reopens with scenes of revolt and revolution from escaped Equisapiens. It is revealed that the white powder Cash inhaled at Lift's party was the formula to turn him into this human-horse hybrid. The film ends with Cash as an Equisapien leading his fellow hybrids to Lift's house, breaking in with the greeting, "Sorry to bother you" (Riley, 2018). Granted, Sorry to Bother You is a satirical film, though Cash realizes through his own trials and tribulations that the capitalist system and White dominance within it should be exposed.

\section{Representations and Critiques of Capitalism in Sorry to Bother You}

Sorry to Bother You is an intentional capitalist critique, thus there are plentiful examples of capitalism from the film to discuss. Major events take place that exemplify how capitalism functions both as an economic system and as an ideology. Because Sorry to Bother You is also satirical, the capitalist representations throughout the film can exemplify the flaws or contradictions within the capitalist system. There are many separate plot points, visual details, character portrayals, and other cues that address and critique capitalism. 


\section{Major Representations of Capitalism}

This film is intended to be a capitalist critique, evident through the stark differences between the telemarketer and Power Caller positions at Regal View, Worry Free's contracted lifetime work scheme, and the celebrated success of human genome mutation for more efficient labor. In fact, the entire structure of the Regal View company is meant to exemplify this American Dream narrative, shown through the idea that the telemarketers can work hard enough to become a Power Caller. The telemarketing managers state that becoming a Power Caller is extremely rare and almost unheard of, exemplifying how becoming a wealthy elite through hard work in the capitalist system is also rare, and most workers will remain within the same social class within their lifetime. The Power Callers operate in a prestigious office on the top floor of the Regal View building, only accessible through an elevator with a comically long password. This represents how inaccessible working one's way up actually is.

As the messages within the film convey real-world capitalism, the film suggests that there is a vast chasm between the social classes in America. More specifically, the structure and details of Regal View epitomize that American culture treats people in different social classes as though they are different kinds of people entirely. The working-class are simply called telemarketers, while the higher-ups are given the grand title of a Power Caller. Because the Power Caller's office is at the top of the building, the company name of Regal View symbolizes how elites in a capitalist system are seemingly on top of the world with a view worthy of royalty. The telemarketers are places literally below the ground, signifying how the working-class in America is thought of and treated like dirt. At the same time, Power Callers are not the highest level of worker at Regal View, as evident in that they are still employed by "management" to make their sales (Riley, 2018). However, the Power Caller boss(es) and management are only mentioned 
and never shown. Riley's choice not to show the boss(es) could be a deliberate one to hint that moving from working-class to middle-class is the only foreseeable and achievable aspiration. This indicates that supreme wealth in the capitalist system is often hidden.

Additionally, the slogan to "stick to the script" is heavily displayed throughout the telemarketer office (a cluttered and dreary basement with a broken snack machine) and is promoted as the only way to become a Power Caller. This slogan is an example of Gramsci's concept of common sense within Sorry to Bother You (1989; Riley, 2018). In the film, it is mentioned that this slogan is passed down from corporate, indicating that the powerful elites, or hegemon, are the ones who provide this ideology to the subaltern. Just as the telemarketers are expected to stick to the script on the phone, they are also expected to simply follow the rules of their socially prescribed, working-class roles.

In Sorry to Bother You, the subaltern are the Regal View telemarketers, including Cash (before he becomes a Power Caller), Detroit, Salvador, and Squeeze. They are seen wearing unkempt clothing that is wrinkly, holey, and ill-fitting to reflect their status as the working-class. These characters often discuss their financial problems, mentioning they are "just out here surviving" (Riley, 2018). Often meeting at a local dive bar, these characters talk about how unfair the Regal View system is as their paychecks do not cover their living expenses. At this time, Cash, Detroit, Salvador, and Squeeze all hold the ideology that capitalism is not a system that benefits all, though Cash somewhat believes that sticking to the script could help him become a Power Caller.

Squeeze takes issue with becoming a Power Caller and calls it a scam. He elaborates to say, "If you work hard enough as a fry cook, maybe you can become a manager, or if you twirl that sign [Detroit is also employed as a sign twirler] really well then maybe you can twirl a larger 
sign on a more glamorous corner" (Riley, 2018). Squeeze does not believe that becoming a Power Caller will solve financial issues, as only the one promoted receives higher pay. In this sense, Squeeze is directly critiquing the capitalist system. By wanting everyone to be paid, Squeeze endorses Marx and Gramsci's belief that sole access to the means of production and sole, individual wealth exploits lower-class workers. Through this criticism of the economy and his job, Squeeze is a driving force toward other characters challenging common sense and establishing good sense. Additionally, by discussing plans for a union strike and work stoppage, Squeeze becomes an exemplar for Gramsci's concept of war of position (Gramsci, 1989).

The telemarketer's strike is a phenomenal example of how Gramsci's (1989) concept of good sense can be adapted and acted upon. Squeeze, the main organizer for the strike, motivates the telemarketers before the first work stoppage by saying, "We fight. Because we make the profits, and they don't share. If we're going to give them our day, we need to have enough to cover our basic necessities. Human decency!" (Riley, 2018). The telemarketers' declaration of needs represents the realization that they are being exploited by Regal View and the capitalist system, demanding more equity in the process. Because the subaltern know they are being exploited and taken advantage of, the strike is an example of Gramsci's (1989) war of position because they show they are aware of the hegemony's injustice and plan to act. In addition to the ongoing strike performed by Regal View telemarketers, toward the end of Sorry to Bother You, there are hints of a revolution involving the genetically modified Equisapiens. Cash leads this revolution with an equal and just ideology, this being evidence of the creation and implementation of good sense in this alternative universe. The Equisapien revolution hints at the final Gramscian theoretical concepts: the war of maneuver. 
Another example of a capitalist critique in Sorry to Bother You is the entire notion of the Worry Free company and the creation of Equisapiens. Signifying real-life capitalism, Worry Free represents the capitalist belief that capital brings power; thus, profits are the ultimate motive. Primarily driven by money, those with excessive profits and power do what they can to maintain their wealth and status. Because capitalism fosters an individualistic mindset, the bourgeoisie feel no responsibility to care for the proletariat, as it would compromise their total capital and power (Marx \& Engels, 1948).

The idea that people are so impoverished that they would volunteer for slavery, quite literally working until death, in exchange for housing is difficult to refute as a clear critique on capitalism. Cash's uncle, who is months behind on rent and is considering working for Worry Free as a contracted laborer, is an example of a subaltern character. The Worry Free employees are also among the subaltern. In one instance, Cash is flipping through channels and watches an interview of a Worry Free worker explaining that the living and working conditions are horrendous and contradict what Worry Free advertises, which is almost expected. The Worry Free workers wear the same uniform, are forced to share beds, are fed unappetizing slop-like meals, and are locked into their rooms at night. As a result, Worry Free also illustrates that struggling within a capitalist system dehumanizes the ones who are struggling.

Scholars note that mass media and advertising have always been used as tools to promote capitalism and to deter the public from paying attention to politics (Behm-Morawitz, Miller, \& Lewallen, 2018; Berger, 2005; Carlson, 1993). Specifically, "the historical role of mass media has always been to promote values that dominate society... the mass media are financed by the business establishment, which rests on assumptions of capitalism, and contributes to the maintenance of that system" (Carlson, 1993, p. 243). The ads for Worry Free show people 
smiling and showing off their situation, but the messages are usually negative or vaguely threatening. One billboard in particular has the message, "If you lived here, you'd be at work already!" written next to the Worry Free logo (Riley, 2018). Serving not only as recruitment tools for slave labor, the advertisements also present a false reality for what it is like to live within Lift's Worry Free environment, and thus, the capitalist system. The Worry Free laborers have to present themselves as though they are happy and well-cared for when the truth is entirely opposite. This shows additional exploitation of the lower-class to benefit the elite, as Lift is the one who profits from the recruitment.

Lift, whose name is meant to show that he is higher [in status] than everyone else, strives to make labor as cheap and efficient as he can. Thus, he is willing to chemically alter human biology to make humans "stronger, more obedient, more durable, and therefore more efficient and profitable" (Riley, 2018). Explaining this plan to Cash, Lift acts as though this endeavor is completely normal and exciting. Lift, being a White man and a member of the hegemon in Sorry to Bother You, holds strong capitalist values. He believes that what he is doing is justified and should be celebrated. Actually, when Cash tries to expose Lift for his Equisapiens, government officials and elites praise Lift for his innovation; giving thus, the film gives support to the notion that the hegemon are self-interested and exploit workers (Gramsci, 1989; Marx \& Engels, 1948). The plot surrounding Worry Free and the Equisapiens distinctly critiques capitalism and capitalist values.

\section{Supplementary Representations of Capitalism}

Regal View, Worry Free, and the creation of Equisapiens represent obvious critiques of the functions of capitalism as an economic system and an ideology. However, there are numerous other representations of capitalism, its flaws, and how it can be critically analyzed in 
Sorry to Bother You. The character Squeeze illustrates how capitalism as both a functioning economic system and ideology can be combatted. When Cash, Detroit, and Salvador begin working for Regal View, they meet Squeeze. As previously mentioned, Squeeze serves as the character who establishes good sense and creates an opportunity for a war of position. It is mentioned in Sorry to Bother You that Squeeze goes around to different companies helping the workers unionize and obtain rights from their employers (Riley, 2018). Considering satire, Riley could be using Squeeze's character to show that people have to go to extremes to resist capitalism, as Squeeze mentions that this is essentially what he does. In this sense, the existence of Squeeze's character indicates that the capitalist system has ongoing inequalities that require continuous intervention and collective action. Squeeze resists capitalism and its ideologies by educating the working-class about how elites are exploiting them for their labor by denying them pay and benefits. He leaves each company after their strikes are successful, showing that his form of resistance against capitalism works. In addition, because he is focused on liberating the working-class rather than pursuing his own acquisition of wealth, he combats the capitalist ideology. However, there is no explanation of his name. Personally, I picture him as "squeezing" money out of the corporations.

At his core, Squeeze seems like the perfect example of how capitalism can be challenged. However, at one point in the film, Squeeze tells Cash that he cannot blame people for ignoring the evils of Worry Free. He tells Cash that the people notice that Worry Free is a problem, but that they feel too powerless to do anything. Specifically, he says, "If you get shown a problem, but don't see a way you can have control over it - you just decide to get used to the problem" (Riley, 2018). Essentially, the problem of capitalism is so big and dynamic that even acknowledging it does not feel like a choice, so people's priorities turn to finding as much peace 
of mind as possible within the system. Because Squeeze's actions directly confront and contest capitalism, Riley's choice to give Squeeze this added layer of complexity helps explain, in relation to real-world capitalism, that complying with the hegemony can be, and often is, simply easier. Resisting capitalism, either through activism, protest, or refusal to work can be risky. The system is designed so that the majority of people have to use their labor to survive because everything costs money. While this exchange is sincere and genuine because Squeeze offers Cash comfort after nobody does anything to prevent Lift from creating Equisapiens, the film is also a satire. The satirical exaggeration of the Equisapiens brings attention to how much exploitation Americans are willing to overlook within our own capitalist system.

Through her actions and apparel, Cash's girlfriend Detroit represents an anti-capitalist theme to Sorry to Bother You. Detroit is first and foremost an artist. She holds several day jobs such as sign twirling and telemarketing at Regal View to pay her bills, but she is ultimately invested in her art. Because her motivations are creative pursuits instead of financial, this alone is an example of how Detroit challenges the capitalist ideals in the film. Detroit is also a member of the Red Eye Faction, an anarchist organization that protests Worry Free. With her talent as an artist, she produces different graffiti pieces that point out the flaws and inequality within capitalism, specifically targeting Worry Free and Lift. For example, she paints "Worry: Slavery at work" over a Worry Free advertisement that originally read, "Worry Free: If you lived here, you'd already be at work" (Riley, 2018).

In the film, there is never any indication that her graffiti work reaches the attention of the elite. Because of this, I cannot tell if she is successful in this form of protest. However, she always smiles when she looks at it, indicating that she feels empowered by her work. Additionally, Detroit creates a life-size papier mâché statue of Lift committing bestiality with a 
horse. Attached to the horse is a sign that read, "Worry Free is turning workers into horses" (Riley, 2018). This statue appears before Cash goes public with the video of Equisapiens. In one scene, a group of people are gathered around the statue discussing the meaning behind it. Detroit walks up to the group, excited to see that this piece is generating conversation and questions about Worry Free. In this piece specifically, Detroit's resistance to capitalism is successful.

In addition to her anarchist work, Detroit also wears multiple pairs of earrings that show anti-capitalist messages. During the work stoppage, she sports a pair of sparkly, pink, and purple penis earrings to signify that the Regal View management can "suck it." Another pair of earrings have the message of "Murder, Murder, Murder/Kill, Kill, Kill" (Riley, 2018). These earrings are shown through an extreme close up directly after a scene when the audience is introduced to the Worry Free company for the first time. The earrings amplify that Worry Free is actually deadly to those who are contracted to work there. Every time she wears a pair of statement earrings, a central character comments on them or compliments them. Because they generate discussion, Detroit's earrings are a successful tool of resistance to capitalism, but on a personal level.

One satirical and heavily exaggerated example of how capitalism is portrayed in the film is through a popular gameshow called I Got the Shit Kicked Out of Me (Riley, 2018). The premise of the show is exactly as how it is titled. People in this alternate reality are willing to be physically assaulted on television for money, showing how desperate some are for any bit of cash. It is mentioned in the film that this show reaches viewership upwards of 150 million. To reiterate, Sorry to Bother You is meant to comment on actual American society and conditions, urging the audience to reflect on the truths revealed in the film. The existence and high viewership of this gameshow suggest straightforwardly that Americans need money. This gameshow also suggests that Americans are desensitized to violence; shows like Worldstar, 
Total Wipeout, and American Gladiator signify that Americans enjoy watching violent content or depictions of people experiencing pain and injury for entertainment value.

\section{Representations and Critiques of Whiteness in Sorry to Bother You}

Sorry to Bother You was written and directed by a Black man, a scarcity in which already challenges the dominance of Whiteness in film and media. Additionally, most of the main cast is Black or from another marginalized ethnic group. The characters and their personalities, identities, and passions are nowhere near stereotypical or tokenized. They are dynamic and interesting, altogether helping push forward a vivacious and spirited understanding of the Black experience, though being Black is not a monolithic experience. Through visual elements and details of the film, the audience receives a more honest and sincere representation of Black people in addition to the satirical components of Riley's vision and capitalist critique. In the film, Whiteness is challenged not only by the narrative and plot, but by the director's influence of casting, visuals, and extended metaphors. It is multi-layered, making it stand out from other films that cover similar issues. This is one of many reasons why it is imperative to further analyze the representations of Whiteness in Sorry to Bother You.

\section{Major Representations of Whiteness}

Although Whiteness is not stated as Riley (2018)'s intentional focus of critique throughout the film, Sorry to Bother You is replete with different ways that racial relations and Whiteness are challenged in society. Cash's friends mention that Cash is only "kind of Black" because he speaks with proper diction (Riley, 2018). This is important to note because throughout the film, Cash's identity as a Black man is observed and often compromised to adhere to Whiteness. Cash becomes a Power Caller only after using his "White voice," as this tool allows him to pass as White enough to enter a predominantly White space as a Black man. 
As aforementioned, the "White voice" is described as how White people wish they could sound or how they feel they should sound. The coworker who tells Cash to use his "White voice" also suggests to Cash that he make the distinction not to sound like Will Smith, or a proper, friendly Black man, but rather as though he does not have a care in the world, as though they are actually worry free (Riley, 2018).

This description of how this character thinks White people should sound influences the way the audience perceives White people and Black people. The film promotes a contrast between the lived realities in that White people do not have to worry about paying their bills, but Black people do. Additionally, within the film, sounding Black on the phone is undesirable. While Sorry to Bother You is a satire and the entire concept of a "White voice" is intended to be comedic, this may leave a negative impact on the audience as it reinforces the idea that Whiteness is to be sought after. Conversely, mentioning how White people think they sound could reinforce the notion that Whiteness is an invisible force within American society, that even White people need to perform to accommodate the presumed standard of being. In this sense, using a "White voice" is an apparent critique on the impact of Whiteness in America.

Similarly, Worry Free's CEO, Lift, is amazed by Cash's ability to succeed in the Whitedominated industry of being a Power Caller. This exemplifies that Lift embraces Whiteness as an ideology (Nakayama \& Krizek, 1995). One instance in which Whiteness was amplified was during Lift's party. Lift coerces and pressures Cash to execute behavior that aligns with stereotypical Blackness and being Black, showing how disconnected Lift is from authentic Black experiences and people. Whether intentional or not, Lift makes Black culture a spectacle to be surveilled by Whites. Being extremely rich, a capitalist, and a White man, Lift represents the 
ultimate hegemon. Because of this, Cash finds it difficult to refuse discussing these topics and is coaxed into using his Blackness as a performance.

Performing one's Blackness is not a recent phenomenon. Calmore (2005) suggests social structures enable or constrain individuals. He continues by arguing that Black performance is primarily fueled through this enabled opportunity to challenge and contest the social structures that restrict freedoms. While gaining access to restricted social structures furthers agency, this access is "not autonomous or transcendent" (Calmore, 2005, p. 110). In other words, Black people have to keep performing different aspects of their Blackness against their will to enter different social structures or groups. Cash performs being White to enter the corporate world as a Power Caller, but then has to perform being Black to enter Lift's social world. By alternating his identity to please others, Riley points to the irony of Cash's situation.

Sitting in the middle of a room with all other party guests surrounding him, Cash is made to talk about "Oakland gangsta' shit," though he states that he has no experience with gangs or violence. Cash is also forced to attempt rapping for a room full of White people even though he repeatedly says he does not want to and is not a skilled rapper. Cash's rap quickly flops and the room is essentially quiet until he starts repeating " $\mathrm{n} *$ gga shit" on beat. Lift's guests begin to sing along, enthusiastically repeating the $\mathrm{N}$-word despite that all of them are White people (Riley, 2018). Here, the subtext of the scene becomes the context as Cash is othered for his Blackness. Though Cash earns approval from Lift for his rapping production, this ultimately brings attention to the fact that Cash is an outsider, or a token, in his work and new social circle.

Bozarth (2019) mentions tokenism in his thesis involving Sorry to Bother You, mentioning that Cash and his White-voice-using mentor Mr. (dubbed by Patton Oswalt), serve as token Black people for the Power Callers and when Cash meets the Worry Free CEO at 
his house for a party. Bozarth (2019) claims that Cash's tokenism supports his corporate success as a Black male in the White-dominated industry, but that he joins the White world at a cost. At this point in the film, Cash is still charmed by the excessive money he makes but has lost his friends and ties to his Black identity in the process. Tokenism in film and other media, when done by White directors, can be damaging and often goes unnoticed. However, in Sorry to Bother You, while Cash serves as a token Black man in his work environment and temporary social circle, he is supposed to. The contrast between him and other Power Callers and party guests is meant to call attention to this disparity, as the film is incredibly successful with challenging notions of Whiteness.

\section{Supplementary Representations of Whiteness}

While using a "White voice" is the strongest representation of how Whiteness is critiqued in Sorry to Bother You, there are other examples within the film. Similar to how she represents critiques of capitalism, Detroit also challenges Whiteness. She exclaims that her parents wanted her "to have an American name;" her name refers to the city in Michigan, which has the highest Black population in America (IndexMundi, n.d..; Riley, 2018). This is not a coincidence, as her character makes style and fashion choices to stand out as a strong, Black, feminist. She wears her hair in natural curls and often sports politically motivated t-shirts with messages such as "The future is female ejaculation" (Riley, 2018).

Like how she critiques capitalism through her earrings, she has pairs that bring attention to the issues of Whiteness in society. Specifically, Detroit wears a pair of earrings that read "Bury the Rag/Deep in Your Face" (Riley, 2018). These are song lyrics from "The Lonesome Death of Hattie Carroll" by Bob Dylan. This song describes the death of a Black barmaid who was killed by a rich farmer in 1963. The farmer's jail sentence was only for six months, 
providing an example of Whiteness and White privilege in America (Wilson, 2018). Another pair of Detroit's earrings are gold plated figures of a man strapped to an electric chair. While these could represent Detroit's opposition to the death sentence in general, they immediately made me think of the mass incarceration problem in America, where Black people are six times more likely to be incarcerated than White people (Tucker, 2016).

Another example of how Whiteness is critiqued in Sorry to Bother You is through the Worry Free advertisements. Berger (2005) claims that "in order to sell goods, advertising has to change attitudes, lifestyles, customs, habits, and preferences while at the same time maintaining the economic system that benefits from these changes" (p. 57). Relating to the film, the cinematic universe Cash lives in appears to completely value capitalism in the economic as well as political and cultural spheres. In another Worry Free billboard, a Black man is sitting on a couch with a cigarette in his mouth, and a television remote and beer in each hand. The message written is, "Show the world you are a responsible babydaddy" (Riley, 2018). As Worry Free is contracted labor, this advertisement tells the public that one must work to have value within the family, indicating that the economic system in place impacts the attitude one can obtain about their own image or identity. Additionally, by using a Black man and the word "babydaddy" (a word associated with African American Vernacular English) in their advertisement, Worry Free is targeting Black men in society, which is one minor way in which Sorry to Bother You employs the concept of Whiteness. Because the film is satirical, this advertisement is intended to portray Black men in a negative light due to the stereotype that Black men are absent or bad fathers (Banjo \& Jennings, 2017). Ironically, if Black men went to work for Worry Free, they would become absent fathers because Worry Free does not allow their workers leave. 


\section{The Intersection of Capitalism and Whiteness in Sorry to Bother You}

Sorry to Bother You is rife with representations of capitalism and Whiteness. Elements of the plot, theme and tone, visual elements, character portrayals, and dialogue show different and unique cues that critique capitalism's economic structure, ideology, and Whiteness. With this in mind, there are also several examples where capitalism and Whiteness intertwine, demonstrating the intimate and complex relationship between the two. Two examples in the film specifically represent this link, being a viral meme and Detroit's art show. Additionally, Cash's overall journey throughout Sorry to Bother You is the primary embodiment of how capitalism and Whiteness intersect.

\section{Supplementary Representations of Capitalism and Whiteness}

As previously mentioned, there are two instances in Sorry to Bother You when critiques of capitalism and Whiteness are both present. The first occurs as a viral meme in this alternate movie universe. During a Regal View protest, the telemarketers attempt to block the Regal View doors to prevent the Power Callers from entering, and thus, making any more sales for Worry Free. Cash is a Power Caller at this time, and in his attempt to walk through the group of protesters, he gets hit in the head by a cola can that was thrown at him. The woman who threw the can exclaims, "Have a soda and smile, bitch" (Riley, 2018). This gets caught on video, resulting in Cash being hit in the head by a cola turning into a viral meme.

This meme becomes a sensation. News outlets play the video, Halloween costumes of a can in Cash's hair are produced, and the White woman who threw the can becomes very famous. She is interviewed on talk shows and even becomes the spokesperson for the cola company, using the slogan of "have a soda and smile, bitch." These events happen rapidly in the film, and this accelerated timeline not only shifts public focus from the protest to the meme but is also a 
satirical exaggeration on how the hegemony can so easily distract the general public with different messages. Additionally, this demonstrates how anyone can become a sellout in the capitalist system, as the protestor becomes a part of what she was originally protesting after receiving endorsements and fame.

This same series of events also challenges racial and Whiteness ideologies. Cash becomes a literal costume as children walk around wearing wigs that resemble his afro. Looking deeper, the White woman chooses to throw a soda can at Cash, a Black man who is trying to make it in the racially biased capitalist system. Riley emphasizes that the capitalist system benefits the White woman more than Cash by having her become incredibly wealthy and famous through the exploitation of Cash. One news anchor even notes that the woman made enough money off of the meme to "buy two white children" (Riley, 2018). This strange and specific indicator of wealth further points to how White people are quite literally worth more than Black people in the film.

Though Sorry to Bother You was written years before its release, this cola can is a satirical parallel to the Kendall Jenner Pepsi ad from 2017. In this ad, reality television star and supermodel Jenner opens up a Pepsi can in the middle of a photo shoot but does not take a sip. As she holds the can, a march for Black Lives Matter passes by her, and she is invited to join through a nod from one of the protestors. Jenner begins marching front and center, eventually standing directly across from a group of militarized police officers who were marching toward the Black Lives Matter group. Jenner walks up to an officer, offering him the Pepsi can she was holding the entire time. The officer accepts the soda, and the two groups of marchers begin to socialize and laugh, appearing to have solved their differences (Rodriguez \& Seri, 2018). By having wealthy, White, and privileged Jenner seemingly end the active protest, this 
advertisement uses Jenner as a White savior, ignores the issue of police brutality, and trivializes the Black Lives Matter movement, all while Jenner profits off of the advertisement. In Sorry to Bother You, a Black man is exploited while a White woman is removed from the labor force as a direct result from his exploitation, while in the meantime, issues of inequality are overlooked.

On the same day that Cash is hit with the soda, Detroit holds the showcase for her art. Detroit's art and art show are another plot point in which capitalism and Whiteness intersect and are critiqued. Detroit's art for her art exhibit is centralized on Africa. She explains to Cash that she "wanted to talk about a life shaped by exploitation. About fighting for a say in our lives. About how beauty, love, and laughter thrive and flourish under almost any circumstances... how capitalism basically started by stealing labor from Africans” (Riley, 2018). Explicitly mentioning capitalism and exploitation, connecting Detroit's art to a capitalist critique is not difficult. By connecting Africa, and by extension, Black people, to capitalism, Detroit's art magnifies the interconnectedness between capitalism and Whiteness, deliberately highlighting the exploitation.

However, Detroit's art show has a different impact than the explanation of her art. To reiterate, Whiteness posits that others should acclimate themselves to fit within its standards. Proving this to be true, Detroit speaks with her very own "White voice" (dubbed by Lily James), wears a crisp white suit, and her hair slicked back, all of which are stark differences to the colorful, political clothing and natural curls she usually wears. Her appearance for her art show is hypocritical, as she has often reprimanded Cash for changing his appearance and using his "White voice" to get ahead as a Power Caller. Instead of pointing this out at her show, Cash initially congratulates her.

During her exhibit, Detroit does an interesting live performance where she repeatedly recites an absurd quote from the 1985 movie The Last Dragon. As she recites the quote, the 
audience is encouraged to throw used cell phones, old bullet casings, and water balloons full of sheep's blood at her. Cash is confused by her performance and asks her to stop, and she remarks, "You of all people should understand. Stick to the script, right?" (Riley, 2018). Detroit's entire showcase shows the complicated relationship between capitalism and Whiteness. Her physical art is focused on Africa, love, and how capitalism started with the exploitation of her ancestors. Yet, her art, focused on exploitation of Blacks, is sold for profit while she attempts to present herself as Whiter. Her absurd performance is entirely satirical.

To reiterate, satire is used to point fingers and place blame on those in power (Condren, 2012). However, Detroit is not a character in a position of power. She is Black, female, and working-class. It seems as though Detroit compromises her activist and anarchist values through conformity of appealing to the status quo or "stick to the script" common sense. She changes her appearance and language patterns through a "White voice" in the pursuit of having a successful art show, insinuating as though she has co-opted herself into this paradigm of paradoxical behavior and ideologies (Nakayama \& Krizek, 1995). However, Detroit seems to be okay with giving an inauthentic performance, as this deception is part of her hustle. Bringing attention to this, Riley (2018) is seemingly blaming this marginalized character for upholding and supporting the system. Because satire is such a complex literary form, the audience may then view Detroit as a sellout, as she appears to compromise her integrity and anti-capitalist and anti-Whiteness ideologies for profit. However, her art show is the only time she is not actively doing something to resist capitalism and Whiteness. In her art show, Detroit takes advantage of and manipulates the oppressive system by giving this inauthentic performance. By essentially giving the people what they want, Detroit can enter into the realm where she can begin to gain attention and status. 
Because she is an activist and anarchist at heart, gaining this attention and status gives her power, thus putting her in a position to create meaningful change within the system.

\section{Cassius “Cash” Green's Journey}

Through following Cash's experiences in the film, one can identify the close relationship of capitalism and Whiteness, as well as how his ideological and material conditions influence each other. To start with, Cash's name immediately brings attention to money and by extent, the economy, indicating that Cash's relationship with money will be a motif throughout Sorry to Bother You. Gathered from the plot summary outlined above, Cash's journey in the film begins with evidence of him financially struggling. Before Cash leaves for his first day of work at Regal View, his uncle reminds him that he is four months late on rent. Cash responds to this by saying, "God made this land for all of us and greedy people like you want to hog it for yourself and your family and charge the rest of us for the right to live" (Riley, 2018). Despite Cash's uncle pointing out the irony in Cash's statement that they are family, Cash's declaration establishes an anticapitalist tone for the film, as this interaction takes place within the first five minutes. Additionally, this statement gives context to where Cash's beliefs and values lie, clearly against the structure of a capitalist economy (Fishbein, 1988; Marx \& Engels, 1948).

At this point in time, Cash is a member of the subaltern. Living on the periphery of power, his life is constricted by the lack of money (Gramsci, 1989). This is evident by different visual details of the materialistic items Cash has in the film. At one point, Cash goes to fill up his car with gas, telling the cashier to put forty on a specific pump, handing her a mere forty cents. Cash is behind on rent, living in his uncle's garage, wears worn and ill-fitting clothing, and has a rusty and beat-up car that smokes when driven (Riley, 2018). Cash seems to trust that his economic hardships are simply the way things are with little he can do to change his situation. 
Joining the strike led by his coworker Squeeze, Cash makes it is evident that he does not endorse the capitalist ideology and chooses actively to resist it.

However, after discovering the influence his "White voice" has, he subscribes to the common sense that achieving an envied Power Caller position is a possibility, eventually becoming his reality. Cash further supports the common sense ideas that capitalism will reward him by working hard and sticking to the script. However, it is Cash's "White voice" that brings him success at work. This proves that any ability to succeed financially is tied to one's ability to "play" White. Blacks can access Whiteness or dominantly White spaces only through presenting as White. Cash using his "White voice" to become a power caller is a direct example of how capitalism and Whiteness are intertwined with each other.

Whiteness, as it is an ideology embedded in social and power relations, influences how Nonwhites live and work in America. In Sorry to Bother You, Cash is able to undermine Whiteness in Regal View based on the assumption that being White is different than Whiteness. In real-world capitalism, there are plenty of Black people who have become financially successful through performing White. Specifically in politics, Black conservatives such a Stacey Dash, Candace Owens, and Congressional Representative Burgess Owens have all worked with conservative news outlet Fox News, speaking about issues that perpetuate Whiteness (BlackPast, n.d.). These conservatives present an image where they are different than those who share their skin color and do not call out the advantages that White people have in America, thus they are playing White, whether it is subconscious or not. However, one does not have to go to the extreme of conservatism to play White and be successful. For example, code-switching is a behavior influenced by Whiteness to succeed in a capitalist system. Because Whiteness is the ideology that White people are the standard and normal, people of color or people who are 
bilingual are sometimes encouraged to sound more professional, or in other words, Whiter (Bozarth, 2019). When Cash uses his "White voice," he is engaging in an exaggerated or satirical form of code-switching, conveying that capitalism is only accessible through Whiteness.

Upon learning that Worry Free sells slave labor, Cash almost backs out of his promotion, that is, until he sees his starting salary. Cash immediately switches to his "White voice," joking that he will need to purchase more suits. After seeing how much money he will make, Cash chooses to exploit workers for profit. When Cash becomes a Power Caller and begins to earn more money, he becomes a part of the gelatinous middle (Gramsci, 1976). Cash's increased wealth and status can be seen though him paying debts to his uncle, moving into a new apartment, getting a fancy car, and buying nice suits for work (Riley, 2018). It appears that Cash is largely motivated by money, which aligns with one of the critiques that Marx has for capitalist values. Furthermore, Cash is so motivated by money that he compromises his moral values to become a Power Caller. By this time, Cash has entirely bought into the capitalist ideology. Cash is not the only one to use a "White voice" in the film. The only other Black Power Caller, Mr. uses a "White voice" and takes on a mentorship role for Cash during his transition into a Power Caller. Both Cash and Mr. ___ only use a "White voice" when they are working whereas before Cash would only use it when he was on the phone with a client. This illustrates that Whiteness is a necessity when interacting with elites such as the other Power Callers. When Cash converses with other Power Callers, he also participates in code-switching, altering his vocabulary to sound more elite. Cash begins to use his "White voice" so often that he sometimes forgets to talk normally. In one scene, Cash wishes Detroit a good morning in his "White voice," admitting that he sometimes does not notice that he is using it (Riley, 2018). Detroit mentions that she does not like Cash's "White voice," to which Cash calls her a 
hypocrite, as she uses one for her art. While the argument appears to concern speaking in a specific voice, it goes deeper into differences in ideology. Detroit uses her "White voice" to sell her art, while Cash uses his "White voice" to sell slave labor. Cash, however, does not admit that he is in the wrong, attempting to defend that he has finally found something he is good at and enjoys just like Detroit and her art. Cash's attempt at a justification for selling slave labor shows how much his ideology has shifted. From being successful in a White-dominated industry, his material wealth and conditions have greatly increased, thus altering his ideology to not think twice about exploiting the working-class. This is necessary to mention, as capitalism, Whiteness, and Gramscian concepts are all impacted by Cash's current position.

While in the gelatinous middle as a Power Caller, Cash removes himself from the ongoing telemarketer strike, thus putting a divide between his friends in the subaltern class and himself. This class divide and Cash's abandonment of the union strike become an issue with his friend, Salvador, who confronts him about selling out. Cash retorts that his success has nothing to do with Sal, but that he supports the strike from the sidelines despite not actually doing anything to help out the telemarketers. This argument between Cash and Salvador is similar to that of how the core tends to pit different subaltern or gelatinous groups against one another in an effort to distract the groups from revolting against the hegemony (Gramsci, 1989). While this interaction is a small part of the overall plot, it is important to note that the spirit of individualism within capitalism drives a wedge into otherwise strong class solidarity.

Within the alternative universe of the film, Lift represents the core or hegemon. As the CEO employs the Regal View Power Callers to make sales for the company, Lift is the ultimate bourgeois elite with the Power Callers not far behind in status. In addition to his job, Lift also lives in a very fancy mansion, decorated with marble statues, large paintings, and extravagant 
furniture. Lift dresses in expensive looking suits and high fashion, both of which symbolize wealth. Gramsci does not mention racial issues, but rather social forces (applicable like race) that contribute to social inequality (Hall, 1986). This knowledge helps support the idea that capitalism and Whiteness are the intersecting forces that help perpetuate the power held by the White CEO of Worry Free and the primarily White Power Callers of Regal View.

At Worry Free CEO Lift's party, Lift encourages Cash to stop speaking in his "White voice" and to sound Blacker. Additionally, Cash is coerced to perform aspects of his Blackness. As aforementioned, this others Cash and he is put on display for Lift and all of his White guests. At the same time, it grants him access to Lift's social circle as his Blackness performance earns Lift's approval. Cash's Blackness performance is based on racial stereotypes about Black culture and Black people. Similar to how Black people can play White to become successful in capitalism, Black people can also use exploit their culture or accentuate certain stereotypes, appealing to White masses, to become rich and famous. There have been accusations that rappers lie about guns and women, both of which are popular themes of rap music, to appeal to a larger audience (Eustice, 2020). Although rap music is a predominantly Black domain, the number of White listeners has increased dramatically over the past several decades (Sullivan, 2003). These embellishments are evidence that Whiteness infiltrates even Black-dominated spaces, influencing people to perform Blackness to be more successful.

As the night goes on, Lift invites Cash into his office for a private meeting. While Cash typically code-switches when interacting with the elite, he mirrors Lift's easy-going and casual personality. Lift offers Cash a job, and eager to advance in social class and appeal to the hegemon, Cash nonchalantly tells Lift that that the details of the job are boring and that he is in for the money alone (Riley, 2018). Cash is fully subscribed to the capitalist ideology at this 
point. Seemingly desensitized to already selling slave labor, Cash at first does not even want to hear about the details of the job. Of course, that is until Cash discovers Lift's plan for human genetic mutation to enhance Worry Free's labor output. While this does not entirely exemplify modern-day capitalism, it is important to note that property owners used breed slaves so they could become stronger (Sublette \& Sublette, 2015). While the genetic mutation to create humanhorse hybrids for stronger and more obedient workers is a satirical exaggeration, this re-imagined slave-breeding connects how capitalism has historically exploited Black people, thus contributing to the perpetuation of Whiteness.

Lift's proposal is to have Cash be the "Equisapien Martin Luther King Jr.... but one we control" for the millions of Equisapiens Lift is planning on creating (Riley, 2018). Undoubtedly satirical, Lift demonstrates his utter racial ignorance and Whiteness by wanting Cash to become just like civil rights activist Martin Luther King Jr. Lift also tells Cash that "they are not like us" when referring to turning the Worry Free laborers into Equisapiens. This shows that Lift believes that he and Cash are essentially better people than the working-class. As is mentioned in chapter two, many believe that the working-class and Black people are synonymous and interchangeable. Riley's choice to include this line is key because he is suggesting that the Worry Free workers are not good enough to be treated like humans, by extension, Black people are less than human.

Cash is offered one hundred million dollars for a five year contract, which he refuses. Cash decides to quit his job as a Power Caller, as he fears that he may become an Equisapien due to a confusion between snorting cocaine and the human-horse fusing catalyst at the party. Over the next few days, Cash is extremely worried about transitioning into this hybrid and pays attention for increased size in of his nostrils and penis, both of which are commonly associated or stereotyped with Blackness. He seeks out Detroit for comfort, who reprimands him for 
rejoining the union strike only because of a negative personal experience with Lift. Here, Detroit holds Cash accountable for his selfish decisions and encourages him to care more about society as a whole, exhibiting the subaltern or class alliances that Gramsci (1989) encourages. Cash realizes he was wrong to accept a Power Caller position, leaves his apartment, moves back in with his uncle, and gives his car to Salvador as an apology for being a bad friend. While a small detail, Salvador accepting the car as an apology from Cash provides evidence that Salvador is also motivated by material possessions.

Cash rejoins his friends in the subaltern and plans the final strike event. Cash releases the Equisapiens from Lift's home to aid in the strike, which becomes a violent riot when militaristic police arrive in an attempt to shut it down. The strike ends up successful for the telemarketers. Several days later, Cash transitions into an Equisapien, and the film ends with Cash appearing to lead a revolution against Lift. As this is the end of Cash's journey for the audience, this revolution can be viewed as Cash employing Gramsci’s war of maneuver (Gramsci, 1989). Overall, Cash's journey in the film begs the audience to challenge their conceptions of capitalistic values and beliefs about Whiteness as Cash's character is a prime example of a critique of capitalism and Whiteness in the media.

The goal of this analysis was to understand the film's messages about the mutual relationship of material and ideological conditions. Cash's journey directly exhibits how material conditions and ideological conditions influence each other. When Cash had no wealth and few material possessions, he held more fair and equitable beliefs. This is shown in his anti-capitalist remark in the beginning of the film with his uncle and his active participation in the first strike event. Cash's attitudes and beliefs about the capitalist system and its ideologies rapidly change when he subscribes to the ideologies of capitalism and Whiteness through using his "White 
voice" to succeed financially. However, Cash misaligns his moral compass to sell slave labor in exchange for large amounts of money. Here, Cash's acquisition of material wealth impacts his ideological state. The more money he has, the less equitable and just his thinking is. Though selling slave labor is a satirical exaggeration, Cash's experiences outline how the capitalist ideology to be motivated by money is damaging and unsustainable.

Leaving his Power Caller position means losing material wealth and possessions. However, Cash's ideological perspectives begin to shift back to anti-capitalist and antWhiteness. The film ends with Cash transforming into an Equisapien, leading his fellow humanhorse hybrid folk to Lift's house for a presumed attack on Lift, who serves as the hegemon in this alternative universe. This hint of rebellion is not only a prime example of Gramsci's war of maneuver but leaves the audience with the impression that revolution against the hegemony is possible.

Overall, the film represents how disadvantageous and pervasive capitalism and Whiteness are. By analyzing and critiquing numerous elements of capitalism and Whiteness in Sorry to Bother You, I argue that Cash's journey demonstrates how the influence of these social forces is strongest when interconnected. Succumbing to these forces, Cash's material conditions and ideological conditions definitively influence each other, teetering back and forth. Cash becomes so enamored and possessed by his material wealth that he is oblivious to his change in ideology. The hegemon is able to manipulate Cash into serving them by distracting him with financial success, though being pushed too far, Cash regains a good sense of the power structures and chooses once again to oppose them. This finding is imperative for understanding Gramsci's concepts as it directly shows how two social forces influence and rely on each other to control individuals. 


\section{CHAPTER V: DISCUSSION}

In summary, I conducted an analysis of Boots Riley's 2018 film Sorry to Bother You. The film is a satirical commentary on actual conditions in America, so I explored how capitalism and Whiteness are represented and interact. My goal was to understand the film's messages about the mutual influence of material and ideological conditions. I did several comprehensive viewings of the film, evaluating the plot, theme and tones, visual details, character portrayals, and dialogue. I

looked for cues that represented capitalism, Whiteness, and Gramscian concepts. Focusing on the central characters, I considered how they dress, their living conditions, the way they talk (e.g., language patters, code switching), and the ideas they have and share through conversation. These cues provided understanding of each character's intentions, motivations, and how they fit into the storyline. Through completing the analysis, I show that there are both major and supplementary representations of capitalism, Whiteness, and their intersection in the film. This intersection supports Gramsci's theoretical framework that two social forces influence and rely on each other. This intersection is necessary to change ideological perspectives and allow the hegemony to maintain its dominance.

\section{Capitalism}

Noting that Sorry to Bother You is an intentional capitalist critique, I found many different ways that capitalism was both represented and critiqued in the film. Most notably, the structure of the Regal View company shows apparent differences between the working-class, upper-middle class, and elite. Exemplifying the working-class or Gramsci's concept of the subaltern, the telemarketers work in a cluttered and drab basement. I discovered that the central characters who are telemarketers are all financially struggling and do not have nice material possessions. This was made evident through their conversations, clothing styles, and living 
conditions. On the contrary, the Power Callers have a fancy office on the top floor of the Regal View building. The film never mentions Regal View CEOs or elites. Because the Power Callers are on the top floor of the building, the film indicates that true wealth in the capitalist system is hidden. The film intentionally offers the working-class a look into how only the gelatinous middle work and live, suggesting that if they happen to break out of their class, they can only aspire to become middle-class because the Power Caller boss(es) are never shown. In addition to these displays of class differences, the slogan "stick to the script" is consistently repeated to the telemarketers, urging them to follow the rules at work and within their prescribed social statuses.

While the living conditions of every character are not shown, there are examples of how the subaltern, gelatinous middle, and hegemon live. Unsurprisingly, poor people live in less affluent communities and are typically cramped in smaller rooms. The gelatinous middle is seen with spacious apartments, but nothing exhibiting excessive wealth. Lift, as the hegemon, lives in an enormous mansion with extravagant decorations, a surplus of food and drink, and a general accumulation of stuff. By presenting poor and rich people this way, the film portrays that through evaluating the material possessions and living conditions people have, we automatically are able to tell what social class they reside in.

Another major representation of capitalism I found in the film was the Worry Free company. Worry Free's contracted slave labor serves as a critique showing how flawed the capitalist system is, as a large portion of the population is impoverished enough to choose working until death in exchange for basic necessities like food, clothing, and shelter. Lift, Worry Free's CEO, perfectly represents a capitalist. He is constantly striving to make labor output more efficient to increase his profit and personal wealth; thus, the Worry Free laborers are treated 
horribly within their overcrowding housing. Additionally, Lift creates human-horse hybrids called Equisapiens as literal work-horses to maximize his profits.

Capitalism is also represented in Sorry to Bother You through the plot surrounding the telemarketer's strike at Regal View, the existence of the gameshow "I Got the Shit Kicked Out of Me," Detroit's anarchism and politically charged earrings, and the advertisements for Worry Free. The strike is a model of how capitalism can be challenged and changed, as the strike is ultimately successful for the telemarketers. The gameshow is a satirical example showing that the public is so desperate for money that they endure a physical beating. Through her anarchist graffiti and earrings, Detroit challenges capitalism by pushing anti-capitalist messages. Both her graffiti and earrings are frequently commented on by other characters, showing that she is successful in bringing her attitudes to people's attention. For most of the film, her graffiti is overlooked by the elite, which may signify that the system allows for these small displays of protest. Her papier mâché statue of Lift and the horse is the only piece of protest art that generates public discussion. Lastly, the advertisements for Worry Free are an example of how the capitalist system exploits the lower-class in the pursuit of profit through the mixed messages seen in the commercials.

\section{Whiteness}

In addition to the numerous representations and critiques I found on capitalism, I was able to uncover several representations on Whiteness. The most prevalent depiction of Whiteness in the film is the use of a "White voice." This is done primarily by Cash to work his way up to become a Power Caller. However, it was also utilized by fellow Power Caller Mr. __ and Detroit during her art show. Having these Black characters use a "White voice" to be successful displays that Whiteness is a standard that must be met for financial prosperity. Additionally, a 
"White voice" is described as how White people think they should sound, which reinforces how Whiteness is invisible in American society to the point of where White people need to perform being White.

Lift's party is another primary example of how Whiteness is represented in Sorry to Bother You. Cash and Mr. __ appear as token characters at the party as they are the only two Black guests at Lift's house. At the party, Cash is pressured into talking about stereotypical Black things, such as gang life in Oakland and rap. Put on display, Cash is coerced into rapping and performing aspects of his Blackness. He is essentially othered by Lift, the other Power Callers, and the party guests.

Other than these two main events, I also found representations of Whiteness within Detroit and another advertisement for Worry Free. Named after the American city with the highest Black population, Detroit's character is a proud, strong, Black, feminist. The art that she creates is centralized on Africa, love, and respect for her ancestry. Additionally, Detroit wears politically charged earrings that critique and challenge Whiteness. Lastly, an advertisement for Worry Free targets Black men and accuses them of being irresponsible fathers. This message is a very obvious representation of how damaging Whiteness in America can be for people of color.

\section{Intersection of Capitalism and Whiteness}

The film's messages about the mutual influence of capitalism and Whiteness are present independently, but the messages are more powerful when combined. This is evident to me through the viral soda can meme, Detroit's art show, but most importantly Cash's overall journey throughout the film. The White woman who hits Cash, a Black man, in the head with a can of cola instantly becomes rich and famous, selling out to become a part of what she was originally protesting. These events paired with the context of the infamous Kendall Jenner Pepsi ad show 
how capitalism and Whiteness can intertwine, since both White women profited off the exploitation of people of color.

Detroit's art exhibit is another example where I found the intersection of capitalism and Whiteness. Detroit's character serves as a strong challenger and disrupter for capitalism and Whiteness, yet during her show she alters her appearance and uses a "White voice" to comply with the standards set by Whiteness. She does this in an attempt to make a profit from her art. While it is possible to interpret this as hypocritical, or that she has compromised her morals for the capitalist ideology, Detroit deserves the benefit of the doubt. Her performance piece is so absurd and satirical that she gives an inauthentic representation of herself as a way to enter a White space where she can make lasting and meaningful change. By giving the audience what they want, she will have a successful art show, therefore obtaining the attention and status necessary to make any social difference.

Finally, Cash's journey throughout the film is the best representation of how capitalism and Whiteness intersect. Cash manifests the capitalist ideal of the American Dream by transforming from working-class to Power Caller. However, this is not possible without complying with the standards that Whiteness sets by using his "White voice." Cash is motivated by money and enjoys material items with his newfound wealth as a Power Caller. At the same time, Cash compromises his Blackness for Lift's entertainment and fully endorses the capitalist ideology through selling slave labor in exchange for wealth. Upon hearing Lift's plan to create Equisapiens, Cash realigns his moral compass, leaves his profitable Power Caller job, and returns to critiquing capitalism and Whiteness by joining the strike. This eventually leads to a successful revolution against Lift and Worry Free. Conclusively, Sorry to Bother You presents an argument for how destructive and pervasive capitalism and Whiteness are, especially when interwoven. 
Cash's journey best represents the film's messages about the mutual relationship of material and ideological conditions. Cash initially holds equitable and fair ideologies, but his acquisition of material items and monetary wealth influence him to lose sight of his anticapitalist and anti-Whiteness ideologies. I demonstrate in this thesis how material conditions and ideological conditions vacillate back-and-forth. Bleak material conditions influence firm egalitarian ideological conditions, such as anti-capitalism and anti-Whiteness. Conversely, Cash's journey shows how abundant material conditions influence weakened ideological conditions.

\section{Theoretical Implications}

Considering all of Gramsci's (1989) theoretical concepts, I determine that hegemony manifests as the capitalist structure and Whiteness, the hegemon and gelatinous middle are represented in the White characters, and the subaltern are represented in the Black characters and other people of color. The common sense is found within the slogan "Stick to the script." This slogan references the idea of the American Dream, a largely unrealistic ideal rooted in capitalism. Squeeze is the character who mainly holds and promotes Gramsci's concept of good sense, as he is the organizer for the strike against Regal View. Squeeze, Detroit, and Salvador are subaltern characters who plan and participate in strike, and eventually, the revolution. Thus, they conduct the actions representing Gramsci's concepts of war of position and war of maneuver.

Sorry to Bother You is an excellent example of showing the different layers and levels of intersection for social frameworks. My findings, specifically those that deal with the intersection of capitalism and Whiteness, provide context to help others understand Gramsci's concepts. While Gramsci did not specifically discuss race or racialized issues in his writings, his concepts can be applied to different social forces to analyze power structures (Hall, 1986). Because neither 
economic class nor race on their own are sufficient enough to sustain hegemonic control, their interaction and reliance on each other is how the hegemony maintains its dominance. This is evident throughout Cash's journey in the film.

Cash only becomes financially successful in the capitalist system when he adopts typical White behaviors, such as his "White voice." He alters aspects of his Black identity, appealing to the dominant, White ideology that one must conform in order to present and act as White. At the same time, he abandons his initial equitable and anti-capitalist ideologies when he becomes a Power Caller, showing that he now fully endorses the ideology associated with capitalism. Cash consents to being dominated by both capitalist and White ideologies simultaneously. These social forces are most powerful when they intersect. Cash is so consumed by his material wealth that he does not notice he has become morally bankrupt. By distracting Cash with monetary gains, the hegemon is able to manipulate him into serving them. This finding is crucial for understanding Gramsci's concepts as it directly shows how two social forces influence and rely on each other to control individuals.

\section{Practical Implications}

The analyses in this thesis provide useful information aiding in bodies of scholarship in capitalism, Whiteness, and media representations for both social forces. Most notably, material and ideological conditions influence each other and teeter back-and-forth. People who follow capitalism as an economic structure tend to be money-oriented, self-interested, and driven by material conditions. My findings suggest that in the film, the more wealth and material items one acquires, the less they acted upon any beliefs in equality and fairness. This reflects supporting research on how greed is a driving force in the capitalist system, perpetuating a class divide between the bourgeoisie and the proletariat (Marx \& Engels, 1948; McGowan, 2013). The more 
money and material wealth that business owners acquire, the less they are willing to distribute to their workers.

My findings admittedly do little to advance the concept of Whiteness. I did not uncover any new information that was not already supported in the existing literature, yet the literature did support my findings that characters of color have to adjust themselves to fit in with the standards of Whiteness (Nakayama \& Krizek, 1995). Thus, my findings aid to the scholarship of Whiteness in media. While there is already an abundance of literature (Erigha, 2015; Mastro, 2015; Nakayama \& Krizek, 1995) on understanding and critiquing Whiteness, we still need to combat the standards it sets. This film presents more genuine and non-stereotypical representations of people of color. Though the film is a satire, the portrayals of Black characters do not play into the satirical aspect of the film, compared to the other exaggerated elements present. Riley demonstrates that the Black experience in current American society is the only authentic thing to come out of the intersection of capitalism and Whiteness. Again, this film does not present any damaging stereotypes that are overabundantly found in Hollywood. However, due to the fact that I am White, my perspective on this is limited because I cannot truly understand the Black experience and harmful effects of Hollywood's negative representations. Therefore, more research is warranted from non-White, academic perspectives.

Lastly, my findings contribute to understanding the satirical genre and how satire works within media in 2021. While satire typically points fingers at only the elites or those in power, Riley (2018) uses satire to call out everyone. Specifically, Riley highlights Detroit and Cash's behavior when they essentially sell-out in pursuit of profit. This can be interpreted both as a critique on the marginalized characters and as a glorification of them for taking advantage of their situation. As supported by previous research, the risk of misinterpretation of satirical 
content is always present (Johnson et al., 2015). For this reason, it is paramount for audiences to educate themselves and others, regardless of where they stand on the ideological spectrum.

\section{Limitations and Future Research}

There were several limitations to this thesis that should be noted. As Sorry to Bother You is a fairly new film, there is a lack of prior research. Because of this, many of the sources I cite involving the film are either from news' sites or culture blogs. These types of sources may contain biases that I did not detect in my research, putting my argument at risk of being too onesided. Additionally, I would like to have included more research on satire. While the film is satirical, it did not occur to me as I was researching to include examples of how satire has been tied to capitalism and Whiteness before.

Furthermore, I admit that my biases likely reinforce my findings. As a critical scholar, I hold discerning views of capitalism and Whiteness. While this made analyzing the film enjoyable and interesting, I realize my findings are constrained within the realm of possibility that my analysis was corrupted through confirmation bias. Moreover, I am White. Because of this, my understanding of experiencing the oppression of Whiteness is limited. I can acknowledge the damaging Whiteness ideology in America and recognize its infiltration in all aspects of society, but my skin color gives me the privilege of not being othered because of Whiteness, like the Black characters in the film. Therefore, it is imperative to note that my depictions of the characters' Blackness come from a privileged perspective and cannot fully comprehend the depth of the struggles and narrative. However, my analysis and interpretation of the film can boost awareness of these struggles for Nonblack audiences.

As Gramsci's concepts can be applied to analyze how social forces interact and influence each other, future research should explore alternative social frameworks other than capitalism 
and Whiteness. For instance, Detroit held a very prominent role in the film, yet she was the only central character who identifies as a woman. Analyzing the film in terms of gender could be interesting, as the film could easily be analyzed through a feminist lens. Other theories or theoretical frameworks that could work with Sorry to Bother You could be cultural-identity theory, social identity theory, and identity management theory. These theories all analyze how identity is formed through the groups or culture one is a part of. Critical race theory would also be very applicable as it analyzes the relationship between race and power.

\section{Conclusion}

In sum, this thesis investigated satirical portrayals of capitalism, Whiteness, and how they interact within Sorry to Bother You, with a focus on describing messages about the mutual influence of material and ideological conditions. By using Gramscian concepts as a theoretical framework, I reveal that the intersection of multiple dominant social forces can impact how and what individuals believe in the film.

The findings also suggest that both capitalism and Whiteness work as invisible frameworks within American society. They often go unnoticed, and therefore are unchallenged. Conversely, both capitalism and Whiteness are incredibly visible in current society. American culture is infatuated with consumption. With capitalism, people flaunt large houses, fancy cars, the latest tech gadget. Concerning Whiteness, companies worldwide are hosting workshops and seminars to educate people on their White privilege. People all over social media bring attention to how Whiteness and White privilege impact marginalized communities. At the same time, there are many who oppose these measures to expose Whiteness. Recently, many have been vocal about outlawing teaching critical race theory in schools or cancelling education that provides new interpretations of the immense impact slavery has had in society (Gerstmann, 
2021). Essentially, capitalism and Whiteness are two highly visible systems in which some are attempting to make invisible.

These two forces are unquestionably recognizable on their own. This is seen through evidence in Sorry to Bother You as well as in current American society. However, my findings indicate that these systems are interdependent and reinforce each other. Deeply intertwined for centuries, class status and race are presumed by many to be synonymous. This is not a coincidence, as capitalism exploits race to sustain itself and the class divide. Additionally, Whiteness relies on capitalism to maintain a dominant ideology through disadvantaging marginalized communities. Therefore, it is the point of intersection where they become invisible.

These frameworks are damaging and pervasive because they perpetuate systems of domination to control the general public while the elite remain in power, as shown through the results of this thesis. Although capitalism and Whiteness are so deeply rooted in American society, critiquing these dominant systems exposes the inequalities within them. Exposure can lead to understanding, which can then lead to challenging the elite and holding them accountable. A society unplagued by classist and racial domination may seem like an improbability, but change is possible, and I am hopeful. 


\section{REFERENCES}

Ackerman, A. (2014). Comedy, capitalism, and a loss of gravity. Discourse, 36(2), 139-175. https://digitalcommons.wayne.edu/discourse/

Allen, T. (1994). The invention of the white race (Vol. 1). Verso.

Anderson, J., \& Kincaid, A. D. (2013). Media subservience and satirical subversiveness: The Daily Show, The Colbert Report, The propaganda model and the paradox of parody. Critical Studies in Media Communication, 30(3), 171-188. https://doi.org/10.1080/15295036.2013.771276

Annis, S. (2019). Parasite. Journal of Religion \& Film, 23(2), 1-5. https://digitalcommons.unomaha.edu/

Banjo, O. O., \& Jennings, N. A. (2016). Content analysis of the portrayal of White characters in Black films across two decades. Mass Communication and Society, 20(2), 281-309. https://doi.org/10.1080/15205436.2016.1230220

Beaudoin, B. B. (2008). Culture, race, and difference through a media lens. The International Journal of Diversity in Organizations, Communities and Nations, 8(5), 145-152. http://www.Diversity-Journal.com

Behm-Morawitz, E., Miller, B. M., \& Lewallen, J. (2018). A model for quantitatively analyzing representations of social class in screen media. Communication Research Reports, 35(3), 210-221. https://doi.org/10.1080/08824096.2018.1428544

Berger, A. A. (2005). Media analysis techniques (3rd ed.). Sage.

BlackPast. (n.d.) Political activists - Black conservatives. https://www.blackpast.org/tag/political-activists-thinkers-conservative/ 
Bozarth, H. (2019). Racism and resistance: Contextualizing sorry to bother you in the neoliberal moment [Master's thesis, University of Oklahoma]. ShareOK. https://hdl.handle.net/11244/319695

Burton, J. A., \& Weller, C. E. (2014). Supersize this: How CEO pay took off while America's middle class struggled. Center for American Progress, 1-10. https://cdn.americanprogressaction.org/wp-content/uploads/kf/CEO_Pay_WEB_Final.pdf

Brabec, M. (2019). Interconnection of class and race with capitalism. Perspectives on Global Development and Technology, 18, 36-46. https://doi.org/10.1163/15691497-12341503

Carlson, J. M. (1993). Television viewing: Cultivating perceptions of affluence and support for capitalist values. Political Communication, 10(3), 243-257. https://doi.org/10.1080/10584609.1993.9962982

Carroll, W. K. (2010). Crisis, movements, counter-hegemony: In search of the new. Interface: A Journal For and About Social Movements, 2(2), 168-198. https://www.researchgate.net/publication/274780718_Crisis_Movements_CounterHegemony_in_search_of_the_new

Chatput, C. (2011). Affect and belonging in late capitalism: A speculative narrative on reality TV. International Journal of Communication, 5, 1-20. https://ijoc.org/index.php/ijoc/article/view/552

Chidester, P. (2008). May the circle stay unbroken: Friends, the presence of absence, and the rhetorical reinforcement of whiteness. Critical Studies in Media Communication, 25(2), 157-174. https://doi.org/10.1080/15295030802031772 
Collum, D. D. (2018). What works: The church's position on labor has been widely disregarded in the United States, but Sorry to Bother You is a sign change could be coming. U.S. Catholic, 38(11), 38-39. https://www.uscatholic.org/november201811/is-the-churchsteaching-on-labor-gaining-more-ground/

Condren, C. (2012). Satire and definition. Humor, 25(4), 375-399. https://doi.org/10.1515/humor-2012-0019

Constable, C. (2018). Challenging capitalism. Science Fiction Film and Television, 11(3), 417448. https://doi.org/10.3828/sfftv.2018.25

Erigha, M. (2015). Race, gender, Hollywood: Representation in cultural production and digital media's potential for change. Sociology Compass, 9(1), 78-89. https://doi.org/10.1111/soc4.12237

Eustice, K. (2020). Billie Eilish says there's a lot of lying going on in rap. HipHopDX. https://hiphopdx.com/news/id.54391/title.billie-eilish-says-theres-a-lot-of-lying-goingon-in-rap\#

Feeney, N. (2016). Spike Lee, Jada Pinkett Smith to skip Oscars after no black actors were nominated. TIME. https://time.com/4184380/spike-lee-oscar-boycott-oscarssowhite/ Fishbein, L. (1988). The business of America...: American labor and the souring of the American Dream. Film and History: An Interdisciplinary Journal of Film and Television Studies, 18(4), 94-96. https://muse.jhu.edu/article/400414/pdf\#info_wrap

Gabriel, J. (1996). What do you do when minority means you? Falling Down and the construction of "whiteness." Screen, 37(2), 129-151. https://doi.org/10.1093/screen/37.2.129 
Gerstmann, E. (2021). Should the States ban critical race theory in schools? Forbes.

https://www.forbes.com/sites/evangerstmann/2021/07/06/should-the-states-ban-criticaltheory-in-schools/?sh=a286766111a0

Gramsci, A. (1976). Selections from the prison notebooks. Q. Hoare (Ed.). Lawrence and Wishart.

Gramsci, A. (1989). Selections from the prison notebooks of Antonio Gramsci (Q. Hoare \& G. Nowell-Smith, Eds.). International.

Green, M. E. (2015). Gramsci and subaltern struggles today: Spontaneity, political organization and Occupy Wall Street. In M. McNally (Ed.), Antonio Gramsci (pp. 156-178). Palgrave.

Gring-Pemble, L., \& Watson, M. S. (2003). The rhetorical limits of satire: An analysis of James Finn Garner's Politically Correct Bedtime Stories. Quarterly Journal of Speech, 89(2), 132-153. https://doi.org/10.1080/00335630308175

Hall, S. (1986). Gramsci’s relevance for the study of race and ethnicity. Journal of Communication Inquiry, 10(2), 5-27. https://doi.org/10.1177/019685998601000202

Hammond, B. (2013). The shoreline in the sea: Liminal spaces in the films of James Cameron. Continuum: Journal of Media \& Cultural Studies, 27(5), 690-703. https://doi.org/10.1080/10304312.2013.824864

IndexMundi. (n.d.). List of the 100 largest cities ranked by Black population percentage. https://www.indexmundi.com/facts/united-states/quick-facts/cities/rank/black-populationpercentage

Johnson, A., del Rio, E., \& Kemmitt, A. (2010). Missing the joke: A reception analysis of satirical texts. Communication, Culture \& Critique, 3, 396-415. https://doi.org/10.1111/j.1753-9137.2010.01077.x 
Jordan, M. (2002). Marxism, not manhood: Accommodation and impasse in Seamus Heaney’s Beowulf and Chuck Palahniuk's Fight Club. Men and Masculinities, 4(4), 368-379. https://doi.org/10.1177/1097184x02004004006

Kendrick, J. (1999). Marxist overtones in three films by James Cameron. Journal of Popular Film and Television, 27(3), 36-44. https://doi.org/10.1080/01956059909602807

Landy, M. (1994). Film, politics, and Gramsci. University of Minnesota Press.

Lang, C. (2018, July 20). Sorry to Bother You director Boots Riley on art, activism and the optimism of fighting back. Time. https://time.com/5341385/boots-riley-sorry-to-botheryou-interview/

Lewallen, J., Miller, B., \& Behm-Morawitz, E. (2016). Lifestyles of the rich and famous: Celebrity media diet and the cultivation of emerging adults' materialism. Mass Communication and Society, 19, 253-274.

https://doi.org/10.1080/15205436.2015.1096945

Loshitzky, Y. (2012). Popular cinema as popular resistance. Third Text, 26(2), 151-163. https://doi.org/10.1080/09528822.2012.663971

Marx, K. (1964). Selected writings in sociology and social philosophy (T. B. Bottomore \& Maxamilien Rubel, Eds.; T. B. Bottomore, Trans.). McGraw-Hill.

Marx, K., \& Engels, F. (1948). Manifesto of the Communist Party (F. Engels, Ed.; S. Moore, Trans.). International Publishers.

Mastro, D. (2015). Why the media's role in issues of race and ethnicity should be in the spotlight. Journal of Social Issues, 71(1), 1-16. https://doi.org/10.1111/josi.12093 
McCarthy, N. (2021). America's most staggering CEO-to-worker pay ratios [Infographic].

Forbes. https://www.forbes.com/sites/niallmccarthy/2021/07/15/americas-moststaggering-ceo-to-worker-pay-ratios-infographic/?sh=5aad8f042c56

McGowan, T. (2013). The capitalist gaze. Discourse, 35(1), 3-23. https://doi.org/10.13110/discourse.35.1.0003

McGowan, T. (2015). Accumulation and enjoyment on Mulholland Drive. The Comparatist, 39, 101-115. https://doi.org/10.1353/com.2015.0006

Mills, C. W. (1997). The racial contract. Cornell University Press.

Mishel, L., \& Kandra, J. (2020, August). CEO compensation surged 14\% in 2019 to $\$ 21.3$ million. Economic Policy Institute. https://www.epi.org/

Molina-Guzmán, I. (2016). \#OscarsSoWhite: How Stuart Hall explains why nothing changes in Hollywood and everything is changing. Critical Studies in Media Communication, 33(5), 438-454. https://doi.org/10.1080/15295036.2016.1227864

Morgan, K. (2021, February 18). Assessing COVID-19's impact on Black communities. Elsevier. https://www.elsevier.com/connect/atlas/

Mussaumi, B., \& Aryal, Y. (2012). Beyond the "Techniques of Domination:” Affect, capitalism and resistance. Journal of Philosophy: A Cross-Disciplinary Inquiry, 7(18), 64-76. https://doi.org/10.5840/jphilnepal201271817

Nakayama, T. K., \& Krizek, R. L. (1995). Whiteness: A strategic rhetoric. Quarterly Journal of Speech, 81(3), 291-309. https://doi.org/10.1080/00335639509384117

Olson, J. (2004). The abolition of white democracy. University of Minnesota Press. 
“Oppressed white"-as-revolutionary: How the Young Patriots Organization's "hillbilly" selfdetermination undermines the hegemony of white supremacy. (2019). Conference Papers - American Sociological Association, 1-24.

Ott, J. (2013). Good question, nice answer, but why without happiness? Journal of Happiness Studies, 15, 737-740. https://doi.org/10.1007/s10902-013-9494-z

Price, C. C., \& Edwards, K. A. (2020). Trends in income from 1975 to 2018. RAND Corporation, 1-62. https://doi.org/10.7249/wra516-1

Reklis, K. (2018, September 25). BlacKkKlansman, Sorry to Bother You, and the "white voice." The Christian Century. https://www.christiancentury.org/article/screentime/blackkklansman-sorry-bother-you-and-white-voice

Riley, B. (Director). (2018). Sorry to bother you [Film]. Annapurna Pictures.

Rodriguez, A., \& Seri, K. (2018, February 27). Keeping up with Kendall and Pepsi rhetorical analysis. Adriana Rodriguez Blogs. https://you.stonybrook.edu/

Sculos, B. W. (2019). Sorry to Bother You with twelve theses on Boots Riley's "Sorry to Bother You": Lessons for the left. Class, Race and Corporate Power, 7(1). https://doi.org/10.25148/crcp.7.1.008320

Siegel, M. L. (2002). Germinal: Teaching about class and industrial capitalism through film. Radical History Review, 83, 180-185. https://doi.org/10.1215/01636545-2002-83-180

Sublette, N., \& Sublette, C. (2017). The American slave coast: A history of the slave-breeding industry. Lawrence Hill Books.

Sullivan, R. E. (2003). Rap and race: It's got a nice beat, but what about the message? Journal of Black Studies, 33(5), 605-622. https://doi.org/10.1177/0021934703251108 
Talib, N., \& Fitzgerald, R. (2015). Inequality as meritocracy. Critical Discourse Studies, 12(4), 445-462. https://doi.org/10.1080/17405904.2015.1034740

Torchin, L. (2019). Alienated labor's hybrid subjects: Sorry to Bother You and the tradition of the economic rights film. Film Quarterly, 72(4), 29-37. https://doi.org/10.1525/fq.2019.72.4.29

Tucker, R. B. (2016). The color of mass incarceration. Ethnic Studies Review, 37-38, 135-149. https://doi.org/10.1525/esr.2017.37_38.1.135

Tukachinsky, R. (2015). Where we have been and where we can go from here: Looking to the future in research on media, race, and ethnicity. Journal of Social Issues, 71(1), 186-199. https://doi.org/10.1111/josi.12104

Weber, M. (2002). The Protestant ethic and the spirit of capitalism. Routledge.

Wilson, T. (2018, July 31). Let's talk about Detroit's iconic earrings in 'Sorry to Bother You.' Black Girl Nerds. https://blackgirlnerds.com/

Wilson, V. (2020, June 22). Inequities exposed: How COVID-19 widened racial inequities in education, health, and the workforce. Economic Policy Institute. https://www.epi.org/publication/covid-19-inequities-wilson-testimony/

Wolpe, H. (1986). Class concepts, class struggle, and racism. In J. Rex \& D. Mason (Eds.), Theories of race and ethnic relations (pp. 110-130). Cambridge University Press.

Wood, E. M. (2015). Class, race, and capitalism. Political Power and Social Theory, 15, 275284. https://doi.org/10.1016/s0198-8719(02)80027-8

Younkins, E. W. (2014). Exploring capitalist fiction: Business through literature and film. In Independent Review (Vol. 19, pp. 133-137). Independent Institute. 
Zacharek, S. (2018, July 5). Review: Sorry to Bother You may be the most culturally relevant movie of the year. Time. https://time.com/5331075/review-sorry-to-bother-you-lakeithstanfield/

Zompetti, J. (2012). The cultural and communicative dynamics of capital: Gramsci and the impetus for social action. Culture, Theory, and Critique, 53(3), 1-18.

https://doi.org/10.1080/14735784.2012.721628 